\title{
Low-temperature thermochronology and thermokinematic modeling of deformation, exhumation, and development of topography in the central Southern Alps, New Zealand
}

\author{
Frédéric Herman, ${ }^{1}$ Simon C. Cox, ${ }^{2}$ and Peter J. J. Kamp ${ }^{3}$ \\ Received 22 July 2008; revised 13 March 2009; accepted 2 July 2009; published 9 October 2009.
}

[1] Apatite and zircon (U-Th)/He and fission track ages were obtained from ridge transects across the central Southern Alps, New Zealand. Interpretation of local profiles is difficult because relationships between ages and topography or local faults are complex and the data contain large uncertainties, with poor reproducibility between sample duplicates. Data do form regional patterns, however, consistent with theoretical systematics and corroborating previous observations: young Neogene ages occur immediately southeast of the Alpine Fault (the main plate boundary structure on which rocks are exhumed); partially reset ages occur in the central Southern Alps; and older Mesozoic ages occur further toward the southeast. Zircon apparent ages are older than apatite apparent ages for the equivalent method. Three-dimensional thermokinematic modeling of plate convergence incorporates advection of the upper Pacific plate along a low-angle detachment then up an Alpine Fault ramp, adopting a generally accepted tectonic scenario for the Southern Alps. The modeling incorporates heat flow, evolving topography, and the detailed kinetics of different thermochronometric systems and explains both complex local variations and regional patterns. Inclusion of the effects of radiation damage on He diffusion in detrital apatite is shown to have dramatic effects on results. Geometric and velocity parameters are tuned to fit model ages to observed data. Best fit is achieved at $9 \mathrm{~mm} \mathrm{a}^{-1}$ plate convergence, with Pacific plate delamination on a gentle $10^{\circ} \mathrm{SE}$ dipping detachment and more rapid uplift on a $45-60^{\circ}$ dipping Alpine Fault ramp from $15 \mathrm{~km}$ depth. Thermokinematic modeling suggests dip-slip motion on reverse faults within the Southern Alps should be highest $\sim 22 \mathrm{~km}$ from the Alpine Fault and much lower toward the southeast. Citation: Herman, F., S. C. Cox, and P. J. J. Kamp (2009), Low-temperature thermochronology and thermokinematic modeling of deformation,

\footnotetext{
${ }^{1}$ Earth Sciences Department, ETH Zurich, Zurich, Switzerland.

${ }^{2}$ GNS Science, Dunedin, New Zealand.

${ }^{3}$ Department of Earth and Ocean Sciences, University of Waikato, Hamilton, New Zealand.

Copyright 2009 by the American Geophysical Union. 0278-7407/09/2008TC002367\$12.00
}

exhumation, and development of topography in the central Southern Alps, New Zealand, Tectonics, 28, TC5011, doi:10.1029/ $2008 \mathrm{TC} 002367$.

\section{Introduction}

[2] The Southern Alps of New Zealand are a particularly good location to investigate mountain-building processes. They are formed adjacent to the Alpine Fault, which is arguably the best global example of a crustal-scale obliquereverse fault. The orogen is young and active, resulting from the ongoing rapid collision between the Pacific and Australian plates (Figure 1), and has recently been the focus of much international research [e.g., Okaya et al., 2007]. Many authors [Norris et al., 1990; Koons, 1990, 1994; Beaumont et al., 1996; Batt and Braun, 1999; Beavan et al., 2007; Little et al., 2007] have suggested the orogen is comparable with doubly vergent models in which a critical wedge is bounded by two oppositely dipping structures (Figure 2): the retroshear and proshear (adopting the definitions introduced by Willett et al. [1993] (Figure 2b). The retroshear is represented by the Alpine Fault, accumulating a greater proportion of the deformation and accommodating a large proportion of the plate motion [Norris and Cooper, 2001]. The proshear is the locus of instantaneous deformation, and leads to the formation of an array of back shear or back thrust structures, which are antithetic to the Alpine Fault and are progressively advected into the orogen and do not accumulate large finite strains (Figure 2).

[3] There are plenty of exposed faults within the central Southern Alps which might be considered proshear type structures, including the Main Fault Divide Zone (MDFZ) [Cox and Findlay, 1995]. However, although these faults are clearly exposed (Figure 3) and appear to have a close relationship with the shape of topography and drainage [Cox and Findlay, 1995; Herman and Braun, 2006], evidence for active Holocene motion appears to be obscured or missing due to high erosion rates and youthful landscape [Cox and Sutherland, 2007]. Fault studies are unable to constrain exactly where the current locus of deformation occurs east of the Alpine Fault, and hence provide indirect information on the nature of structures at depth. While geodetic GPS surveys of contemporary deformation may provide some clues, they are limited to measuring horizontal deformation and may be influenced by seismic cycle fluctuations [Beavan et al., 2007].

[4] In this paper, we present results from low-temperature thermochronological dating across the central Southern 

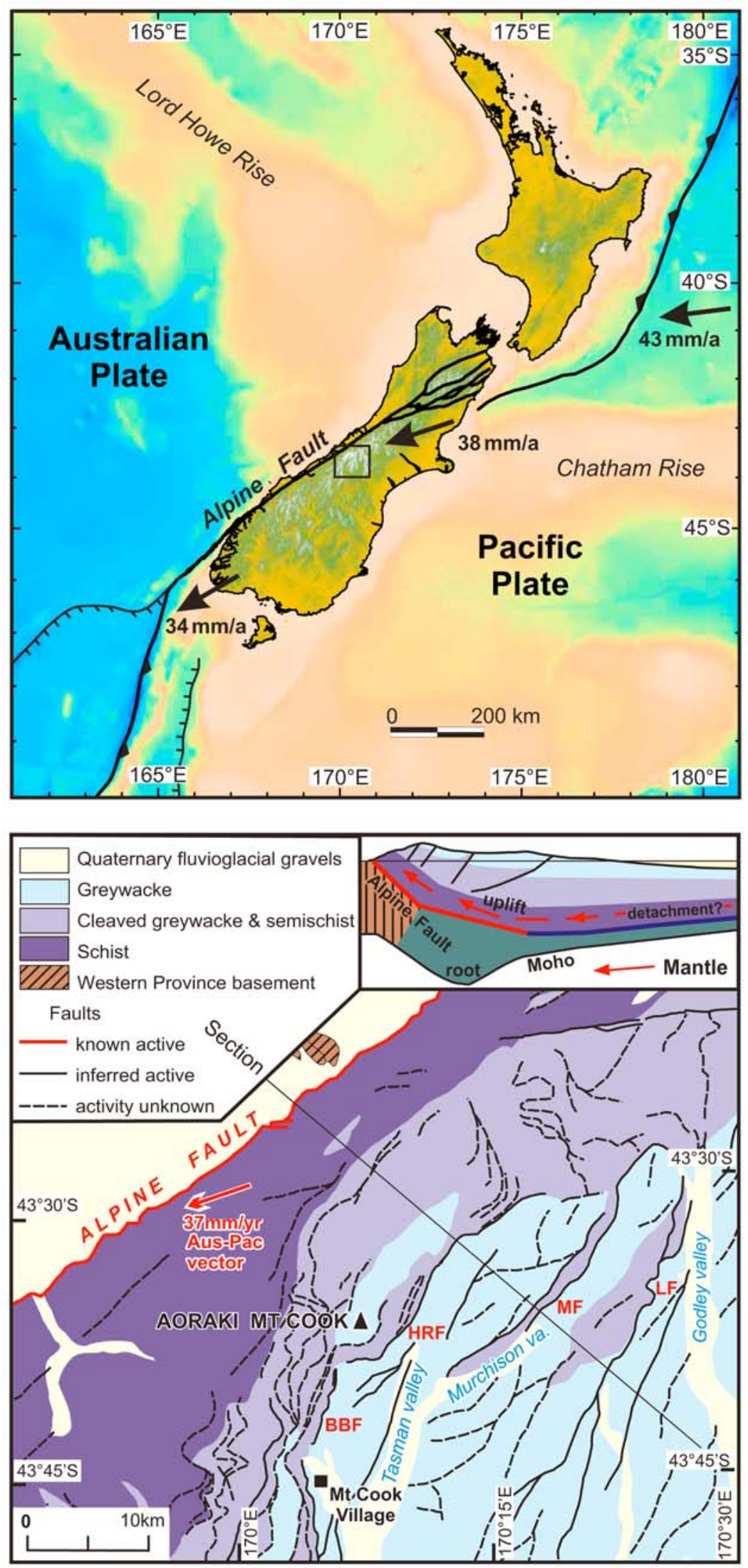

Figure 1 
Alps to further constrain the regional boundary conditions to the crustal deformation. In particular, we assess the geometry of the Alpine Fault ramp and low-angle detachment zone (Figure 2), the nature of fault movement on the proside of the range, as well as the relationships between deformation, exhumation and the development of the topography. The new data are concentrated on the southeastern (pro)side of the Southern Alps, while most previous thermochronological studies have focused on the western (retro)side of the mountains. We begin by introducing the general tectonic setting of the area and report new thermochronological data that are based on apatite and zircon (U-Th)/He and fission track (FT) dating. In the second part, we develop a 3-D thermokinematic model of the orogen using the most commonly adopted convergent wedge and detachment zone model of the upper crust. We vary geometric and velocity parameters to test how they may affect thermochronologic results, and find the boundary conditions which best fit observed thermochronological data.

\section{Regional Setting}

[5] Neogene dextral compression across the AustralianPacific plate boundary has uplifted rocks underlying the Southern Alps into the path of westerly dominated air circulation. This results in a dramatic orographic weather pattern, with heavy rainfall $\left(\geq 10 \mathrm{~m} \mathrm{a}^{-1}\right)$ on the western side of the mountains and a rain shadow $\left(\leq 1 \mathrm{~m} \mathrm{a}^{-1}\right)$ in the east [Griffiths and McSaveney, 1983]. Erosion appears to correlate strongly with precipitation [Adams, 1980; Hicks et al., 1996]. Correspondingly, there has been differential exhumation across the Southern Alps [Kamp et al., 1989] that influences the mechanical behavior of the orogen and concentrates deformation in the Pacific plate [Koons et al., 2003]. It is generally believed that the incoming Pacific plate delaminates at about $25-30 \mathrm{~km}$ depth with east tilted middle and upper crustal material brought to the surface in the hanging wall of the Alpine Fault, while lower crustal material is either added to an orogenic root or subducted with the Pacific lithospheric mantle [e.g., Wellman, 1979; Batt and Braun, 1997, 1999; Little et al., 2007; Okaya et al., 2007]. Evidence for a low-angle detachment is not strong, with the $25-30 \mathrm{~km}$ depth inferred, indirectly, from metamorphic assemblages exhumed in the hanging wall (requiring temperature and geothermal gradient assumptions), thermochronology, and interpretation of geophysical experiments [Little et al., 2005; Okaya et al., 2007]. The modern convergent regime is thought to have started between 10 and 5 Ma [Walcott, 1998; Batt et al., 2000; Sutherland, 1995], although the change from a transform to convergent regime through continental New Zealand could be as old as $20 \mathrm{Ma}$ [Cande and Stock, 2004]. The current relative plate motion has a large strike-slip component $\left(33-40 \mathrm{~mm} \mathrm{a}^{-1}\right)$ compared with its shortening component $\left(8-10 \mathrm{~mm} \mathrm{a}^{-1}\right)$ [Beavan et al., 2007].

[6] A near-continuous mid-upper crustal geological section is exposed across the Southern Alps in rocks of the Torlesse composite terrane [Cox and Barrell, 2007] (Figure 1) [Grapes and Watanabe, 1983; Little et al., 2005]. Midcrustal mylonites and amphibolite facies Alpine Schist occur immediately adjacent to the Alpine Fault, and contain evidence of a Neogene ductile deformation overprint that constructively reinforced and reoriented preexisting Mesozoic metamorphic fabrics in these rocks [Little et al., 2002a, 2002b; Norris and Cooper, 2003]. An exhumed, fossil, brittle-ductile transition zone (Figures $2 \mathrm{~b}$ and 2c) [Little et al., 2002b; Wightman and Little, 2007] separates Alpine Schist in central Southern Alps from semischist and relatively undeformed graywacke that were metamorphosed during the Mesozoic, but suffered only brittle effects during the Neogene compression [Cox and Findlay, 1995; Cox et al., 1997].

[7] A series of major northwesterly dipping faults are exposed on the eastern side of the Southern Alps, striking slightly oblique to the Alpine Fault and dipping in the opposite direction. The MDFZ [Cox and Findlay, 1995] occurs immediately east of the Southern Alps crest and the divide separating drainage flowing to the north and west from that flowing south and east. The fault zone juxtaposes homoclinal semischist sequences against lesser metamorphosed graywackes [Cox and Findlay, 1995]. Similar faults are exposed immediately east of the two other high mountain ranges with topography consistently over $2500 \mathrm{~m}$. These principal faults are shown in Figure 3. From northwest to southeast, these are the Black Blob Fault (BBF) in the Hooker Valley, the Haast Ridge Fault (HRF) in the Tasman Valley, the Murchison Fault (MF) in the Murchison Valley and the Liebig Fault (LF) in the Godley Valley. Slickensides indicate predominantly dip-slip motion, and a reverse sense of displacement is indicated by subtle changes in metamorphic and textural grade across the faults and internal structures within the fault zones. A difference in FT ages across the Black Blob Fault was cited as evidence for late Neogene ( $\leq 5 \mathrm{Ma}$ ) displacement by Cox and Findlay [1995]. Reverse motion on these faults appears to oppose the westward thrusting of the Pacific plate across the Alpine Fault, leading to the notion that they are reverse back thrusts [Wellman, 1979; Cox and Findlay, 1995; Little et al., 2002a, $2002 \mathrm{~b}$ ]. Under this scenario, deformation on these structures may occur either as the horizontal motion of the Pacific plate impinges against the Alpine Fault ramp and is converted to uplift, or in a more general response to middleupper Pacific plate compression as it is delaminated, uplifted and tilted eastward above a low-angle detachment zone [Little et al., 2007]. Since they strike slightly oblique

Figure 1. Pacific/Australian plate boundary. (top) Collision in the framework of the Pacific/Australian plate boundary. The black line shows the plate boundary. Black arrows show Pacific plate motion relative to Australia. Subduction polarity to the north and south of the South Island is illustrated with black arrow heads. (bottom) Regional geology of the Southern Alps [Cox and Sutherland, 2007]. Faults referred to in the text are labeled BBF, Black Blob Fault; HRF, Haast Ridge Fault; MF, Murchison Fault; and LF, Liebig Fault. Inset is a cross-sectional view in the central Southern Alps. 
(A)

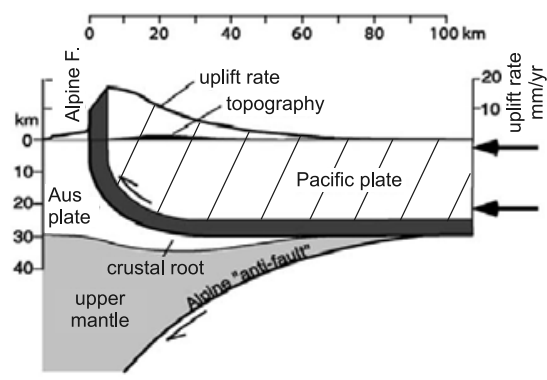

(B)

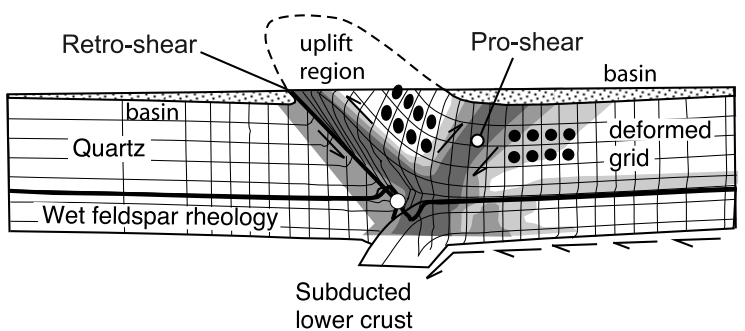

(C)

zone of

zone of brittle-

reverse-oblique ductile shear

bands

active shears

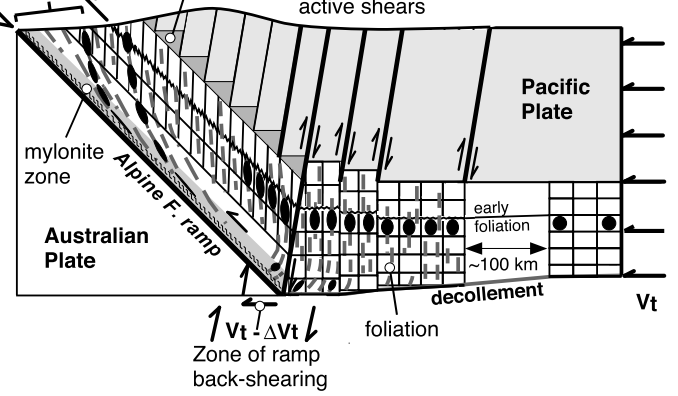

(D)

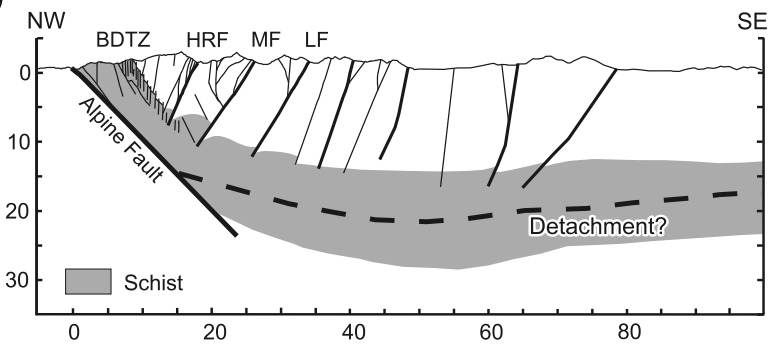

Figure 2. Geodynamic models of the Southern Alps of New Zealand. (a) Upthrusting of the Pacific plate onto the Australian plate [Wellman, 1979]. (b) Results from a thermomechanical model (modified from Beaumont et al. [1996]) in which collision is accommodated by mantle subduction. (c) Idealized cross-sectional structural model of the orogen (modified from Little et al. [2002a, 2002b] and Little [2004]). (d) NW-SE cross section, drawn exactly to scale with no vertical exaggeration, showing the Alpine Fault, reverse back thrusts, and topography across the orogen.

to the Alpine Fault, the motion accommodates components of both plate boundary perpendicular shortening and plate boundary parallel deformation. Over half of the plate motion is accommodated on the Alpine Fault [Norris and
Cooper, 2001, 2007] so it has been argued the faults should develop in the outboard part of the orogen, be active for a limited period only, before being carried westward by plate motion and exhumed [Cox and Findlay, 1995; Herman and Braun, 2006; Little et al., 2007]. However, there is potential that these faults also record a protracted deformation history, possibly forming in response to either Mesozoic or Paleogene tectonic events, quite distinct from the present Neogene plate boundary architecture and compression [Long et al., 2003].

\section{Low-Temperature Thermochronology}

[8] In this section, we outline the rationale behind using low-temperature thermochronology to better constrain displacement across faults and regional exhumation patterns. We then outline our analytical methods and report the analytical results.

\subsection{Rationale}

[9] Low-temperature thermochronology is based upon radiogenic decay processes including the rates of production of daughter products through radiogenic processes and the retention or loss of those products from host minerals through diffusion (noble gases) or annealing (fission tracks). Thermochronologic methods enable quantification of the timing and rates at which rocks cool and approach the surface during exhumation [e.g., Dodson, 1973]. Zircon FT and $(\mathrm{U}-\mathrm{Th}) / \mathrm{He}$ ages record the cooling history of rocks below about $230^{\circ}$ and $190^{\circ} \mathrm{C}$, respectively [e.g., Brandon et al., 1998; Reiners et al., 2004]. At a locality that has been subject to steady exhumation, zircon ages should be older than apatite ages; which are closed in the temperature intervals of $80^{\circ}$ to $110^{\circ} \mathrm{C}$ for FT and $40^{\circ}$ to $100^{\circ} \mathrm{C}$ for (U-Th)/He [e.g., Green et al., 1989; Farley, 2000; Shuster et al., 2006]. Some previous investigations examined faults in detail, using thermochronological data to constrain the timing and rates of movement and footwall and/or hanging wall exhumation [e.g., Grasemann and Mancktelow, 1993; Harrison et al., 1997]. Because of their low closure temperature, (U-Th)/He and FT dating have also been used to infer the evolution of the topography [e.g., House et al., 1998; Braun, 2002; Ehlers and Farley, 2003; Herman et al., 2007a].

[10] As part of this study we collected (U-Th)/He and FT data for zircon and apatite in sample transects across the principal faults in the central Southern Alps, aiming to obtain information on the nature of fault displacements, the boundary conditions controlling the crustal deformation, and to better understand the evolution of topography on the eastern side of the Main Divide and conditions in which the rocks are passing through the orogen and being exhumed.

\subsection{Analytical Methods}

[11] Apatite and zircon crystals were separated from graywacke sandstone using standard rock crushing and mineral separation methods. (U-Th)/He ages were measured on apatite and zircon aliquots of 12 to 17 and 3 to 5 grains, 


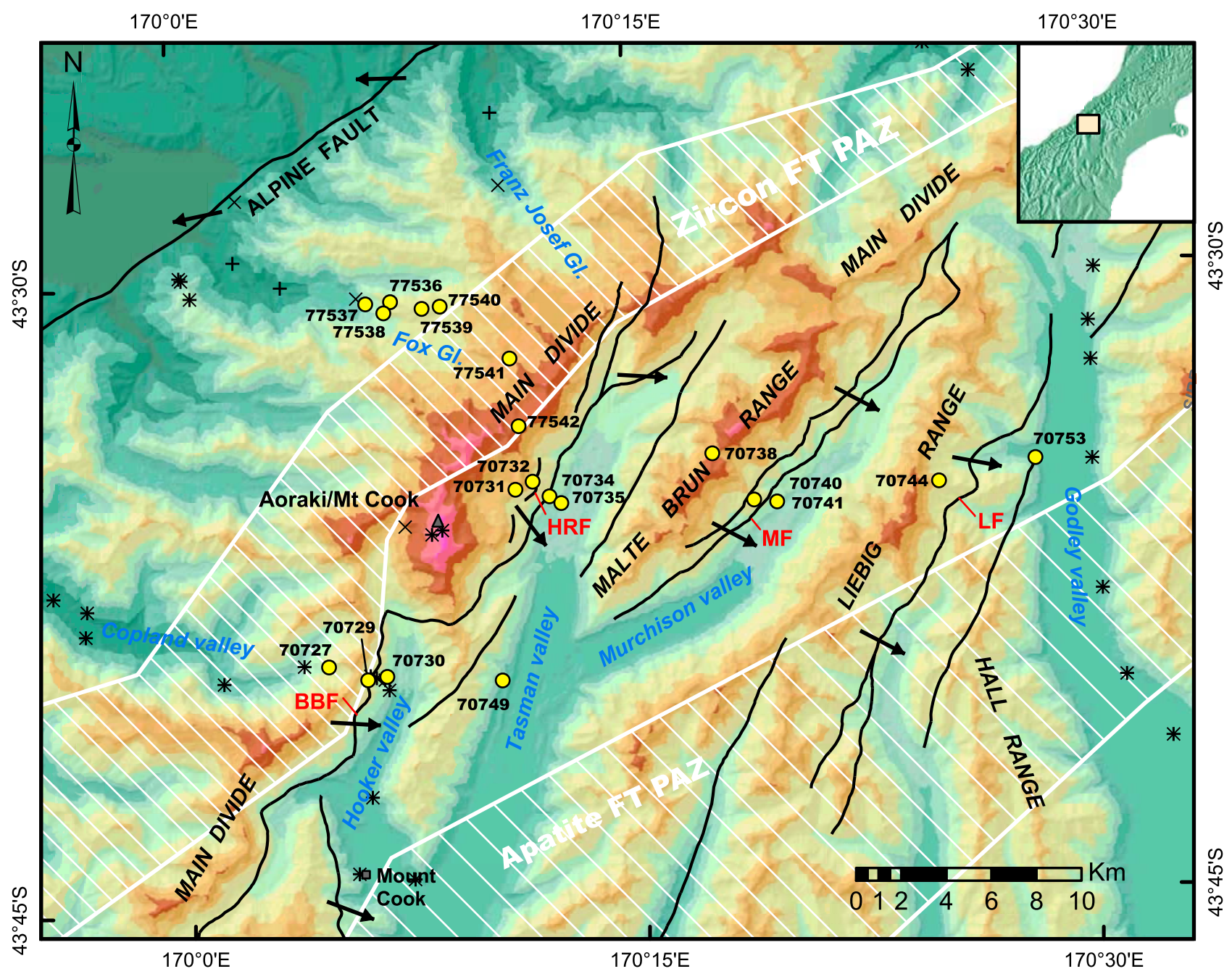

Figure 3. Digital elevation model of the central Southern Alps. The location of samples analyzed in this study (yellow circles) are labeled with the New Zealand national rock and mineral collection number (PETLAB P numbers). Black lines highlight the location of the most important reverse faults (Alpine Fault; BBF, Black Blob Fault; HRF, Haast Ridge Fault; MF, Murchison Fault; LF, Leibig Fault, see Figure 1), with arrows showing the direction of the hanging wall motion relative to the footwall as defined by slickenside measurements (see Cox and Herman (manuscript in preparation, 2009) for details). The location of zircon (crosses) and apatite (pluses) fission track analyses in previous studies and the position of exhumed zircon and apatite partial annealing zones are shown for reference [see Tippett and Kamp, 1993; Batt et al., 2000].

respectively. Dated crystals were handpicked from separates using a microscope and screened to exclude grains with large inclusions. To ensure that inclusion-free and crack-free minerals were analyzed, crystals were optically screened under clove oil and then ethanol. Grains with good crystal habits were selected to permit the calculation of the $\alpha$ ejection correction [Farley et al., 1996]. The crystals were loaded in platinum foil tubes that were heated for 15 to $20 \mathrm{~min}$ at $1250^{\circ} \mathrm{C}$ for zircon and $1050^{\circ} \mathrm{C}$ for apatite using a $\mathrm{Nd}$ :YAG laser connected to a low-blank helium line. Temperatures were controlled using an optical pyrometer. Evolved gas was purified by $\mathrm{Zr}-\mathrm{Al}$ alloy getters and measured by ${ }^{3} \mathrm{He}$ isotope dilution using a quadrupole mass spectrometer. The crystals were reheated at similar temperatures to ensure complete extraction of helium. The reproducibility of the standard ${ }^{3} \mathrm{He}$ spike was tested before and after most measurements. Once retrieved from the line, zircons were dissolved in Teflon bombs using a $\mathrm{HNO}_{3}$ and $\mathrm{HF}$ mixture. Apatites were dissolved in $\mathrm{HNO}_{3}$. Uranium and thorium concentrations were measured by ${ }^{233} \mathrm{U}$ isotope dilution, with an additional control provided by a standard solution containing $\mathrm{U}$ and $\mathrm{Th}$ to monitor mass fractionation on an Agilent ICP-MS.

[12] Duplicate aliquots were analyzed for most samples. Many duplicates had poor age reproducibility, typically varying by $20 \%$ but some by over $100 \%$. Their variability 
is considerably larger than a $2 \sigma$ analytical uncertainty and the $3-5 \%$ relative standard uncertainty commonly quoted for $(\mathrm{U}-\mathrm{Th}) / \mathrm{He}$ ages [e.g., Reiners and Brandon, 2006]. Other studies in which variation in apatite $(\mathrm{U}-\mathrm{Th}) / \mathrm{He}$ ages also exceed the analytical uncertainty appear to be common, and it is clear that the dominant uncertainty is not just derived from analytical measurement. Instead, variation is attributed to factors that cause variance in He retentivity within crystals, such as slow cooling rates, chemical composition or the size of crystals [e.g., Farley et al., 1996; Fitzgerald et al., 2006; Flowers et al., 2007; Herman et al., 2007b]. Age uncertainties quoted in this study have been based on a combination of analytical uncertainties and uncertainties in the measurement of crystal size (radius R and length $\mathrm{L}$ ). The $2 \sigma$ measurement uncertainties were estimated for $\mathrm{R}$ and $\mathrm{L}$, then used to generate a root mean square uncertainty for $\alpha$ ejection by assuming the size population is normally distributed and the microscope resolution was $2.5 \mu \mathrm{m}$. Uncertainties from combined analytical and size uncertainties are large, varying between 20 to $40 \%$. In order to decrease the uncertainties in similar setting and rock lithology, future studies should consider analyzing large numbers of duplicates [e.g., Berger et al., 2008].

[13] FT ages were determined on splits of the apatite and zircon concentrates for which (U-Th)/He ages had been determined. Standard techniques for sample preparation, calibration and analysis were used, and apatite and zircon mounts were irradiated following the methods described by Green et al. [1986] and Kamp et al. [1989]. Nominal fluences of $1 \times 1016$ thermal neutrons $\mathrm{cm}^{-2}$ for apatite and $2 \times 1015$ thermal neutrons $\mathrm{cm}^{-2}$ for zircon were used and track densities were determined by the external detector method. For zircon samples we used the multimount and variable etch time technique [Garver and Kamp, 2002] to determine fission track densities. The multimount and variable etch time technique optimizes the total range of countable grains by the etching of several zircon mounts for different times $(15,30,60 \mathrm{~h})$ and counting of fission tracks within grains from each mount. All uncertainties are quoted at the $1 \sigma$ level.

\subsection{Results}

[14] At a regional scale and within uncertainties of the data, most of the new thermochronological ages are consistent with the theoretical systematics for steadily exhumed rocks, with zircon apparent ages older than apatite apparent ages for the equivalent method. However, some apatite FT ages appeared to be younger than apatite (U-Th)/He ages. Measured ages are reported in Tables 1 and 2 and plotted with respect to distance southeastward from the Alpine Fault (Figure 4). Late Neogene ages are observed near the Alpine Fault and are progressively older with distance toward southeast, which corroborates previously published FT and (U-Th)/He results [Tippett and Kamp, 1993; Batt et al., 2000; Herman et al., 2007a, 2007b].

[15] Zircon FT ages have been reset in Alpine Schist adjacent to the Alpine Fault, reflecting late Neogene uplift and exhumation from conditions at which zircon fission tracks fully anneal, whereas zircon FT ages are of Mesozoic or of Paleozoic age at distances $\geq 15 \mathrm{~km}$ from the fault, southeast of the Main Divide Fault Zone.

[16] Less than $5 \mathrm{Ma}$ zircon (U-Th)/He ages are observed in the vicinity of the Alpine Fault. Ages between 5 and $20 \mathrm{Ma}$ were obtained in the Hooker and Tasman valleys from hanging wall sequences of the Black Blob and Haast Ridge faults (shown as partially reset ages in Figure 4a). The host rocks cooled through $\sim 190^{\circ} \mathrm{C}$ temperature during the Miocene and Early Pliocene, as the Australian-Pacific plate boundary developed, before the topography in mountains formed during the Pliocene and Pleistocene. The ages reflect partial retention of helium due to thermally activated diffusion and are distinct from the Paleogene-Mesozoic ages obtained for zircon in the footwall of the faults and rocks further southeast. Footwall sequences, together with those either side of the Murchison and Liebig faults, have resided above the zircon $(\mathrm{U}-\mathrm{Th}) / \mathrm{He}$ partial retention zone since the Paleogene. Some zircon (U-Th)/He ages $\geq 300 \mathrm{Ma}$ arise from unusually $\mathrm{He}$ retentive crystals that record accumulation of helium from before Permian or Middle-Late Triassic deposition of the host grains in these graywacke rocks [Cox and Barrell, 2007].

[17] Apatite FT and (U-Th)/He ages are mostly $\leq 10 \mathrm{Ma}$ (Figure 4b). They represent the accumulation of age recorded by the rock during late Neogene exhumation, and are therefore an indirect record of Southern Alps formation. Older apatite (U-Th)/He and FT ages $\geq 10 \mathrm{Ma}$ are found in Liebig Range $\geq 25 \mathrm{~km}$ from the Alpine fault, representing exhumation from within the respective partial annealing and retention zones. An apatite (U-Th)/He age of $22 \mathrm{Ma}$ in the hanging wall of the Liebig Fault, circa $35 \mathrm{Ma}$ in footwall, is consistent with the reverse sense of motion inferred from metamorphic and textural observations, but because the ages reflect partial retention of He they cannot be used to directly constrain the amount of displacement without conversion to paleotemperatures prior to disturbance or independent correlation.

[18] Elevation versus age plots for sample transects on the sides of Hooker, Tasman and Murchison valleys (across the Black Blob, Haast Ridge and Murchison faults) are presented in Figure 5. Although there are a limited number of ages determined for each transect, it is clear that there are no strongly linear positive age-elevation relationships (AERs) displayed by individual thermochronometric methods. Within the uncertainties, AERs are complex and tend toward being univariant or weakly negative, and stepped or discontinuous across the faults. The profile across the Murchison Fault, which is farthermost from the Alpine Fault, is closest to a simple, positive correlation, and shows the greatest separation in ages between dating methods. The observed AERs suggest that simple interpretation cannot be drawn, and that the structure is complex and/or equal age surfaces have been offset and rotated.

\section{Numerical Modeling}

[19] In this section we outline the motivation behind using a numerical model, present the model setup, and 
Table 1. Apatite and Zircon Fission Track Ages ${ }^{\mathrm{a}}$

\begin{tabular}{|c|c|c|c|c|c|c|c|c|c|c|c|c|c|}
\hline PET & $\mathrm{Lab}$ & $N_{x}$ & $\begin{array}{c}\text { Spontaneous } \\
\rho_{s}\end{array}$ & $\begin{array}{c}\text { Spontaneous } \\
N_{s}\end{array}$ & $\begin{array}{c}\text { Induced } \\
\rho_{i}\end{array}$ & $N_{i}$ & $\begin{array}{c}\mathrm{P}\left(\chi^{2}\right) \\
(\%)\end{array}$ & $\rho_{s} / \rho_{i}$ & $\begin{array}{c}1 \sigma \\
\text { Error }\end{array}$ & $\rho_{d}$ & $N_{d}$ & $\begin{array}{l}\text { Age } \\
(\mathrm{Ma})\end{array}$ & $\begin{array}{c}1 \sigma \\
\text { Error }\end{array}$ \\
\hline \multicolumn{14}{|c|}{ Apatite } \\
\hline P70727 & 0401-35 & 9 & 0.043 & 4 & 3.129 & 294 & 87.4 & & & 1.362 & 3229 & 3.2 & \pm 1.6 \\
\hline P70729 & 0401-36 & 16 & 0.093 & 16 & 3.173 & 548 & 54.8 & & & 1.378 & 3266 & 7.0 & \pm 1.8 \\
\hline P70731 & 0401-32 & 20 & 0.069 & 27 & 3.706 & 1456 & 16.0 & & & 1.346 & 3192 & 4.4 & \pm 0.9 \\
\hline P70732 & 0401-37 & 20 & 0.055 & 24 & 4.154 & 1825 & 37.8 & & & 1.385 & 3284 & 3.2 & \pm 0.7 \\
\hline P70734 & 0401-33 & 20 & 0.071 & 21 & 3.283 & 972 & 82.3 & & & 1.354 & 3210 & 5.1 & \pm 1.1 \\
\hline P70738 & $0401-25$ & 13 & 0.117 & 10 & 2.634 & 225 & 94.3 & & & 1.322 & 3135 & 10.2 & \pm 3.3 \\
\hline P70740 & 0401-26 & 18 & 0.11 & 26 & 4.459 & 1058 & 41.3 & & & 1.330 & 3154 & 5.7 & \pm 1.1 \\
\hline P70741 & $0401-27$ & 20 & 0.091 & 19 & 3.473 & 725 & 98.7 & & & 1.338 & 3173 & 6.1 & \pm 1.4 \\
\hline P70753 & 0401-24 & 20 & 0.527 & 108 & 4.571 & 937 & 0.0 & 0.138 & \pm 0.022 & 1.315 & 3117 & 27.9 & \pm 5.8 \\
\hline P77536 & $9901-43$ & 20 & 0.004 & 1 & 2.554 & 618 & 100.0 & & & 1.373 & 3260 & 0.4 & \pm 0.4 \\
\hline P77537 & $9901-45$ & 20 & 0.004 & 1 & 2.551 & 707 & 99.7 & & & 1.388 & 3297 & 0.3 & \pm 0.3 \\
\hline P77538 & $9901-44$ & 20 & 0.008 & 4 & 2.909 & 1491 & 100.0 & & & 1.377 & 3270 & 0.6 & \pm 0.3 \\
\hline P77539 & $9901-42$ & 20 & 0.019 & 8 & 2.894 & 1247 & 98.4 & & & 1.362 & 3233 & 1.5 & \pm 0.5 \\
\hline P77540 & $9901-46$ & 20 & 0.001 & 3 & 0.366 & 909 & 100.0 & & & 1.396 & 3315 & 0.8 & \pm 0.5 \\
\hline P77541 & $9901-40$ & 20 & 0.039 & 9 & 2.423 & 561 & 99.5 & & & 1.351 & 3205 & 3.8 & \pm 1.3 \\
\hline P77542 & 9901-41 & 20 & 0.026 & 6 & 1.847 & 433 & 98.4 & & & 1.358 & 3224 & 3.3 & \pm 1.4 \\
\hline \multicolumn{14}{|c|}{ Zircon } \\
\hline P70727 & 0401-35 & 19 & 18.83 & 2859 & 7.956 & 1208 & 17.9 & & & 0.724 & 1718 & 113.4 & \pm 4.8 \\
\hline P70729 & 0401-36 & 15 & 14.73 & 2180 & 4.58 & 678 & 0.0 & 3.591 & \pm 0.46 & 0.753 & 1784 & 159.2 & \pm 12.8 \\
\hline P70730 & 0401-31 & 30 & 15.98 & 3594 & 3.45 & 776 & 5.2 & & & 0.738 & 1773 & 224.5 & \pm 10.5 \\
\hline P70731 & 0401-32 & 21 & 16.97 & 3689 & 4.229 & 919 & 1.2 & 4.15 & \pm 0.217 & 0.696 & 1651 & 184.5 & \pm 10.4 \\
\hline P70732 & 0401-37 & 19 & 17.12 & 3266 & 5.326 & 1016 & 0.0 & 3.442 & \pm 0.246 & 0.760 & 1801 & 161.1 & \pm 11.2 \\
\hline P70734 & 0401-33 & 21 & 9.366 & 3591 & 2.689 & 1031 & 0.0 & 3.642 & \pm 0.225 & 0.710 & 1685 & 161.7 & \pm 10.8 \\
\hline P70738 & $0401-25$ & 28 & 17.6 & 3424 & 3.583 & 697 & 41.5 & & & 0.666 & 1581 & 215.0 & \pm 10.6 \\
\hline P70740 & $0401-26$ & 16 & 19.95 & 2537 & 4.522 & 575 & 13.0 & & & 0.675 & 1603 & 196.0 & \pm 10.4 \\
\hline P70741 & $0401-27$ & 21 & 17.65 & 3350 & 3.988 & 757 & 0.3 & 5.001 & \pm 0.327 & 0.702 & 1666 & 214.8 & \pm 14.4 \\
\hline P70744 & $0401-28$ & 18 & 18.83 & 3288 & 4.192 & 732 & 0.0 & 4.851 & \pm 0.402 & 0.711 & 1688 & 211.3 & \pm 15.6 \\
\hline P70749 & $0401-29$ & 17 & 13.41 & 2063 & 3.289 & 506 & 1.0 & 4.24 & \pm 0.302 & 0.668 & 1585 & 178.9 & \pm 13.3 \\
\hline P70753 & 0401-24 & 26 & 15.04 & 3297 & 3.143 & 689 & 0.0 & 5.405 & \pm 0.366 & 0.648 & 1538 & 209.0 & \pm 14.8 \\
\hline P77536 & $9901-43$ & 14 & 0.189 & 34 & 7.204 & 1299 & 90.9 & & & 0.854 & 2023 & 1.5 & \pm 0.3 \\
\hline P77537 & $9901-45$ & 20 & 0.247 & 72 & 15.39 & 4484 & 93.3 & & & 0.864 & 2045 & 0.9 & \pm 0.1 \\
\hline P77538 & $9901-44$ & 20 & 0.181 & 85 & 9.877 & 4640 & 55.6 & & & 0.859 & 2034 & 1.0 & \pm 0.1 \\
\hline P77539 & 9901-42 & 20 & 0.214 & 58 & 6.751 & 1826 & 88.5 & & & 0.849 & 2012 & 1.8 & \pm 0.2 \\
\hline P77540 & $9901-46$ & 20 & 0.002 & 38 & 0.099 & 1728 & 100.0 & & & 0.874 & 2067 & 1.3 & \pm 0.2 \\
\hline P77541 & $9901-40$ & 20 & 0.488 & 112 & 5.539 & 1272 & 99.7 & & & 0.834 & 1979 & 4.9 & \pm 0.5 \\
\hline P77542 & $9901-41$ & 23 & 4.408 & 732 & 4.347 & 722 & 0.0 & 1.173 & \pm 0.121 & 0.839 & 1990 & 56.1 & \pm 7.4 \\
\hline
\end{tabular}

${ }^{a}$ PET refers to samples held in the national rock and mineral collection hosted by GNS Science (for grid refs, descriptions, etc., see http://pet.gns.cri.nz) Abbreviations are $\mathrm{N}_{\mathrm{x}}$, number of crystals; $\rho$ are track densities $\left(\times 10^{6}\right.$ tracks cm$\left.{ }^{-2}\right)$, with subscripts $s$ relating to spontaneous tracks and $i$ relating to induced tracks. All analyses are by the external detector method using 0.5 for the $4 \pi / 2 \pi$ geometry correction factor. Apatite ages were calculated using dosimeter glass SRM 612 and zeta- $612=348.8 \pm 5.5( \pm 1 \sigma)$, zircon ages calculated using dosimeter glass CN1 and zeta-CN1 $=133.5 \pm 1.1$. $\mathrm{P}\left(\chi^{2}\right)$ is the probability of obtaining $\chi^{2}$ value for $\nu$ degrees of freedom (where $\nu$ is the number of crystals -1 ) [Galbraith, 1981]; the pooled $\rho_{s} / \rho_{i}$ ratio is used to calculate age and uncertainty where $\mathrm{P}\left(\chi^{2}\right) \geq 5 \%$; mean $\rho_{s} / \rho_{i}$ ratio is reported for samples where $\mathrm{P}\left(\chi^{2}\right) \leq 5 \%$ and for which central ages [Galbraith and Green, 1990] are calculated. Apatites from some samples have few, long, tracks which affect the statistics of the results. Mean track lengths $(\mu \mathrm{m})$ of these samples $\pm 1 \sigma$ uncertainties, with (SD; number of tracks) in parentheses are P70729 $14.73 \pm 0.46(0.79 ; 3) ; \mathrm{P} 7073115.01 \pm 0.01(0.01 ; 2) ; \mathrm{P} 7073413.30 \pm 1.79$ (3.01; 3$)$; P70732 $14.38 \pm 0.39(0.87 ; 5) ;$ P70753 $14.64 \pm 0.28(0.48 ; 3)$.

then evaluate a series of model results and discuss their implications.

\subsection{Motivation}

[20] The horizontal increase in thermochronological ages with increasing distance southeast from the Alpine Fault is generally thought to be caused by differential uplift and exhumation [Kamp et al., 1989; Tippett and Kamp, 1993; Batt et al., 2000; Herman et al., 2007a] rather than due to a thermal pulse resetting older ages [Adams and Gabites, 1985]. Locally, one may try to interpret the observed AERs. However, several factors such as horizontal spacing between samples, faults, evolving topography and exhumation would rend the interpretation difficult, as explained below.
[21] Samples reported in this study were collected at different distances away from the Alpine Fault and from mountain ridge transects where average slopes are $30-45^{\circ}$, as opposed to vertical walls or drill holes. Univariant or negative AERs, in which older ages are obtained toward the base of the slope, may simply reflect that horizontal location of samples has greater influence on observed ages than vertical location.

[22] Sample transects were obtained and oriented at a high angle to individual faults in the central Southern Alps, near-parallel to their dip-slip vectors and the mean shortening direction across the faults, because the dip-slip motion on these faults is interpreted as responsible for the uplift and cooling of rocks east of the Main Divide. Complex thermal 
Table 2. New Apatite and Zircon (U-Th)/He Ages From the Central Southern Alps ${ }^{\mathrm{a}}$

\begin{tabular}{|c|c|c|c|c|c|c|c|c|c|c|c|c|c|c|c|c|c|}
\hline PET & Field & $\mathrm{N}$ & $\begin{array}{c}\mathrm{L} \\
(\mu \mathrm{m})\end{array}$ & $\begin{array}{c}\mathrm{R} \\
(\%)\end{array}$ & $\begin{array}{c}\mathrm{L} \\
(\%)\end{array}$ & $\begin{array}{c}2 \sigma \mathrm{Er} \\
(\%)\end{array}$ & $\mathrm{Ft}$ & $\begin{array}{c}\mathrm{U} \\
(\mathrm{ppm})\end{array}$ & $\begin{array}{c}\text { Th } \\
\text { (ppm) }\end{array}$ & $\mathrm{Th} / \mathrm{U}$ & $\begin{array}{c}{ }^{4} \mathrm{He} \\
\left(\mathrm{nmol} \mathrm{g}^{-1}\right)\end{array}$ & $\begin{array}{c}\text { Age NC } \\
\text { (Ma) }\end{array}$ & $\begin{array}{l}\text { Analytic } \\
\text { Er (Ma) }\end{array}$ & $\begin{array}{c}\mathrm{Ft} \\
\text { Weighted } \\
\text { Er (Ma) }\end{array}$ & $\begin{array}{c}\text { Age C } \\
\text { (Ma) }\end{array}$ & $\begin{array}{l}\text { Combined } \\
\text { Uncertainty } \\
\text { (Ma) }\end{array}$ & $\begin{array}{c}\mathrm{Er} \\
(\%)\end{array}$ \\
\hline \multicolumn{18}{|c|}{ Apatite } \\
\hline P70727 & COP 1 & 12 & 109 & 0.37 & 0.46 & 0.59 & 0.65 & 9.4 & 14.43 & 1.54 & 0.31 & 0.50 & 0.07 & 0.18 & 0.8 & \pm 0.2 & 38 \\
\hline Dup & & 15 & 138 & 0.25 & 0.40 & 0.47 & 0.69 & 5.66 & 3.87 & 0.68 & 0.37 & 0.70 & 0.09 & 0.18 & 1.0 & \pm 0.2 & 29 \\
\hline P70729 & COP 3 & 15 & 95 & 0.40 & 0.55 & 0.68 & 0.58 & 17.17 & 9.78 & 0.57 & 3.84 & 2.44 & 0.15 & 1.08 & 4.2 & \pm 1.1 & 45 \\
\hline P70730 & COP 4 & 14 & 125 & 0.13 & 0.44 & 0.46 & 0.7 & 6.5 & 9.12 & 1.4 & 0.42 & 0.64 & 0.08 & 0.16 & 0.9 & \pm 0.2 & 28 \\
\hline Dup & & 15 & 113 & 0.40 & 0.45 & 0.60 & 0.65 & 7.71 & 11.54 & 1.5 & 1.12 & 1.33 & 0.17 & 0.47 & 2.0 & \pm 0.5 & 38 \\
\hline P70731 & HAA 1 & 15 & 129 & 0.36 & 0.38 & 0.53 & 0.7 & 26.47 & 37.8 & 1.43 & 5.81 & 2.03 & 0.09 & 0.58 & 2.9 & \pm 0.6 & 29 \\
\hline P70732 & HAA 2 & 15 & 133 & 0.14 & 0.39 & 0.41 & 0.71 & 24.54 & 21.01 & 0.86 & 5.63 & 2.40 & 0.19 & 0.53 & 3.4 & \pm 0.6 & 23 \\
\hline P70734 & HAA 4 & 13 & 136 & 0.28 & 0.43 & 0.51 & 0.69 & 20.44 & 17.77 & 0.87 & 1.34 & 0.78 & 0.06 & 0.22 & 1.1 & \pm 0.2 & 29 \\
\hline Dup & & 15 & 120 & 0.45 & 0.47 & 0.65 & 0.67 & 12.89 & 15.73 & 1.22 & 1.17 & 0.87 & 0.08 & 0.33 & 1.3 & \pm 0.3 & 38 \\
\hline P70735 & HAA 5 & 12 & 140 & 0.21 & 0.39 & 0.44 & 0.74 & 10.92 & 10.73 & 0.98 & 1.65 & 1.90 & 0.14 & 0.42 & 2.6 & \pm 0.4 & 23 \\
\hline Dup & & 12 & 130 & 0.15 & 0.42 & 0.44 & 0.73 & 2.75 & 4.57 & 1.66 & 0.38 & 1.55 & 0.09 & 0.36 & 2.1 & \pm 0.4 & 24 \\
\hline P70738 & MAL 3 & 15 & 118 & 0.43 & 0.42 & 0.60 & 0.66 & 1.67 & 0.02 & 0.01 & 0.6 & 4.45 & 0.42 & 1.56 & 6.7 & \pm 1.6 & 36 \\
\hline P70740 & MAL 5 & 15 & 113 & 0.45 & 0.46 & 0.64 & 0.61 & 10.99 & 2.47 & 0.22 & 1.04 & 1.12 & 0.12 & 0.45 & 1.8 & \pm 0.5 & 41 \\
\hline Dup & & 14 & 109 & 0.16 & 0.50 & 0.52 & 0.68 & 5.57 & 0.13 & 0.02 & 0.61 & 1.44 & 0.11 & 0.42 & 2.1 & \pm 0.4 & 30 \\
\hline P70741 & MAL 6 & 12 & 99 & 0.51 & 0.51 & 0.71 & 0.62 & 15.95 & 19.97 & 1.25 & 1.42 & 1.07 & 0.08 & 0.47 & 1.7 & \pm 0.5 & 45 \\
\hline Dup & & 12 & 106 & 0.19 & 0.51 & 0.55 & 0.66 & 9.22 & 9.62 & 1.04 & 0.84 & 1.13 & 0.06 & 0.36 & 1.7 & \pm 0.4 & 32 \\
\hline P70744 & LIE 3 & 15 & 133 & 0.10 & 0.42 & 0.43 & 0.7 & 3.7 & 8.62 & 2.33 & 7.18 & 15.50 & 0.69 & 3.64 & 22.1 & \pm 3.7 & 24 \\
\hline Dup & & 13 & 128 & 0.10 & 0.38 & 0.40 & 0.7 & 3.67 & 6.64 & 1.81 & 6.59 & 18.00 & 0.85 & 3.91 & 25.7 & \pm 4.0 & 22 \\
\hline P70749 & TAS B & 12 & 115 & 0.11 & 0.43 & 0.44 & 0.67 & 11.65 & 4.96 & 0.43 & 1.37 & 1.66 & 0.08 & 0.42 & 2.5 & \pm 0.4 & 26 \\
\hline Dup & & 15 & 112 & 0.10 & 0.49 & 0.50 & 0.65 & 21.89 & 7.71 & 0.35 & 2.44 & 1.28 & 0.07 & 0.38 & 2.0 & \pm 0.4 & 30 \\
\hline P70753 & GOD 2 & 13 & 120 & 0.28 & 0.47 & 0.55 & 0.67 & 4.29 & 2.36 & 0.55 & 8.01 & 23.50 & 1.02 & 7.42 & 35.1 & \pm 7.5 & 32 \\
\hline \multicolumn{18}{|c|}{ Zircon } \\
\hline P70728 & COP 2 & 5 & 75 & 0.56 & 0.05 & 0.56 & 0.45 & 310.3 & 37.7 & 0.12 & 11.8 & 6.4 & 1.1 & 2.68 & 14.2 & \pm 2.9 & 45 \\
\hline P70729 & COP 3 & 5 & 83 & 0.11 & 0.02 & 0.12 & 0.58 & 445.2 & 70.7 & 0.16 & 9.9 & 4 & 0.5 & 0.30 & 6.9 & \pm 0.6 & 15 \\
\hline Dup & & 5 & 78 & 0.12 & 0.05 & 0.13 & 0.54 & 348.1 & 235.3 & 0.68 & 3.5 & 1.6 & 0.6 & 0.15 & 3.0 & \pm 0.6 & 39 \\
\hline P70730 & $\mathrm{COP} 4$ & 5 & 80 & 0.46 & 0.19 & 0.50 & 0.53 & 171 & 63.2 & 0.37 & 25.1 & 25 & 2.1 & 8.51 & 47.2 & \pm 8.8 & 35 \\
\hline Dup & & 5 & 85 & 0.45 & 0.03 & 0.45 & 0.49 & 743 & 54.7 & 0.07 & 106.9 & 26.4 & 2.3 & 8.42 & 53.9 & \pm 8.7 & 33 \\
\hline P70731 & HAA 1 & 5 & 100 & 0.36 & 0.12 & 0.38 & 0.56 & 770.7 & 276.2 & 0.36 & 15.3 & 3.4 & 0.5 & 0.85 & 6.1 & \pm 1.0 & 29 \\
\hline Dup & & 5 & 72 & 0.11 & 0.09 & 0.15 & 0.57 & 216.2 & 61 & 0.28 & 6.1 & 4.9 & 0.8 & 0.47 & 8.6 & \pm 0.9 & 19 \\
\hline P70732 & HAA 2 & 5 & 105 & 0.40 & 0.04 & 0.40 & 0.61 & 333.8 & 129.2 & 0.39 & 18.7 & 9.5 & 1.2 & 2.36 & 15.6 & \pm 2.6 & 28 \\
\hline Dup & & 5 & 63 & 0.32 & 0.01 & 0.32 & 0.54 & 310.8 & 42.8 & 0.14 & 12 & 6.9 & 0.9 & 1.50 & 12.8 & \pm 1.7 & 25 \\
\hline P70734 & HAA 4 & 5 & 92 & 0.30 & 0.13 & 0.33 & 0.57 & 558.2 & 116 & 0.21 & 29.6 & 9.4 & 1.2 & 2.03 & 16.5 & \pm 2.4 & 25 \\
\hline Dup & & 5 & 82 & 0.47 & 0.15 & 0.50 & 0.55 & 400 & 97.1 & 0.24 & 17.3 & 7.6 & 0.9 & 2.53 & 13.8 & \pm 2.7 & 35 \\
\hline P70738 & MAL 3 & 5 & 87 & 0.20 & 0.14 & 0.24 & 0.58 & 289.5 & 81.6 & 0.28 & 257 & 151 & 23 & 23.89 & 260.3 & \pm 33.2 & 22 \\
\hline Dup & & 5 & 94 & 0.08 & 0.14 & 0.16 & 0.64 & 391.6 & 70.3 & 0.18 & 259.8 & 117 & 10 & 11.12 & 182.8 & \pm 15.0 & 13 \\
\hline P70740 & MAL 5 & 5 & 76 & 0.30 & 0.03 & 0.30 & 0.56 & 992 & 174.1 & 0.18 & 135.9 & 24.4 & 2.3 & 4.85 & 43.6 & \pm 5.4 & 22 \\
\hline Dup & & 5 & 99 & 0.36 & 0.09 & 0.37 & 0.65 & 261.3 & 89.7 & 0.34 & 92.9 & 61.0 & 5.3 & 13.41 & 93.8 & \pm 14.4 & 24 \\
\hline P70741 & MAL 6 & 5 & 68 & 0.43 & 0.27 & 0.50 & 0.5 & 473 & 142.7 & 0.3 & 461.3 & 167 & 14 & 59.31 & 333.0 & \pm 60.9 & 37 \\
\hline Dup & & 5 & 90 & 0.29 & 0.03 & 0.29 & 0.53 & 341.6 & 114 & 0.33 & 344.5 & 171 & 15 & 34.23 & 322.6 & \pm 37.4 & 22 \\
\hline P70744 & LIE 3 & 5 & 98 & 0.40 & 0.16 & 0.43 & 0.62 & 377.2 & 122.1 & 0.32 & 179.5 & 81.5 & 9.0 & 21.83 & 131.5 & \pm 23.6 & 29 \\
\hline Dup & & 5 & 94 & 0.30 & 0.04 & 0.30 & 0.63 & 483.7 & 53.7 & 0.11 & 190.2 & 70.7 & 7.0 & 12.90 & 112.2 & \pm 14.7 & 21 \\
\hline P70749 & TAS B & 5 & 85 & 0.15 & 0.01 & 0.15 & 0.57 & 834 & 264 & 0.32 & 290.2 & 60 & 5.4 & 5.84 & 105.3 & \pm 8.0 & 13 \\
\hline Dup & & 5 & 82 & 0.13 & 0.20 & 0.24 & 0.49 & 1409.1 & 446.1 & 0.32 & 447.8 & 54.7 & 5.3 & 9.49 & 111.6 & \pm 10.9 & 20 \\
\hline P70753 & GOD 2 & 5 & 110 & 0.18 & 0.06 & 0.19 & 0.67 & 103 & 37.4 & 0.36 & 110.5 & 180 & 17 & 20.11 & 268.7 & \pm 26.3 & 15 \\
\hline Dup & & 5 & 98 & 0.31 & 0.11 & 0.33 & 0.63 & 159.7 & 52.2 & 0.33 & 315.5 & 330 & 21 & 65.66 & 523.8 & \pm 68.9 & 21 \\
\hline
\end{tabular}

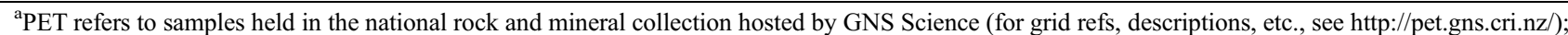
Dup refers to duplicate analysis of the PET sample. Abbreviations are N, number of crystals in sample aliquots; L, mean crystal length; R, mean crystal radius; $2 \sigma \mathrm{Er}=2 \sigma$ measurement error in $\mathrm{R}$ and $\mathrm{L} ; \mathrm{Ft}, \alpha$ ejection factor; $\mathrm{U},{ }^{238} \mathrm{U}$ concentration; Th, ${ }^{232} \mathrm{Th}$ concentration; ${ }^{4} \mathrm{He},{ }^{4} \mathrm{He}$ concentration; Analytic Er, $2 \sigma$ analytical error; Age $\mathrm{C}$, corrected age; Combined uncertainty $( \pm \mathrm{Ma})$ in corrected age from combined analytical and measurement errors.

structure and/or the rotation of equal age surfaces through fault movement can also result in complex, nonlinear AERs [e.g., Kamp, 1997]. Depending on the sense of shear as well as the amount of displacement and/or exhumation that took place on each structure [e.g., Stockli et al., 2000; Ehlers et al., 2003], surfaces of equal age were, or are no longer, horizontal.

[23] Furthermore, it is well known that AERs are influenced by the development of topography [e.g., Stüwe et al., 1994; House et al., 1998; Braun, 2002]. Relief changes strongly affect the distribution of ages with elevation (notably the slope of the AER). For instance, regions that have undergone a steady decrease in surface relief in the recent past could be characterized by a negative AER, that is older ages should be found near valley bottoms and younger ages near summit tops [Braun, 2002]. Furthermore, Braun [2002] showed how the wavelength of the topography, the geothermal gradient, the exhumation rate, and the duration of the relief reduction event can affect observed results. 

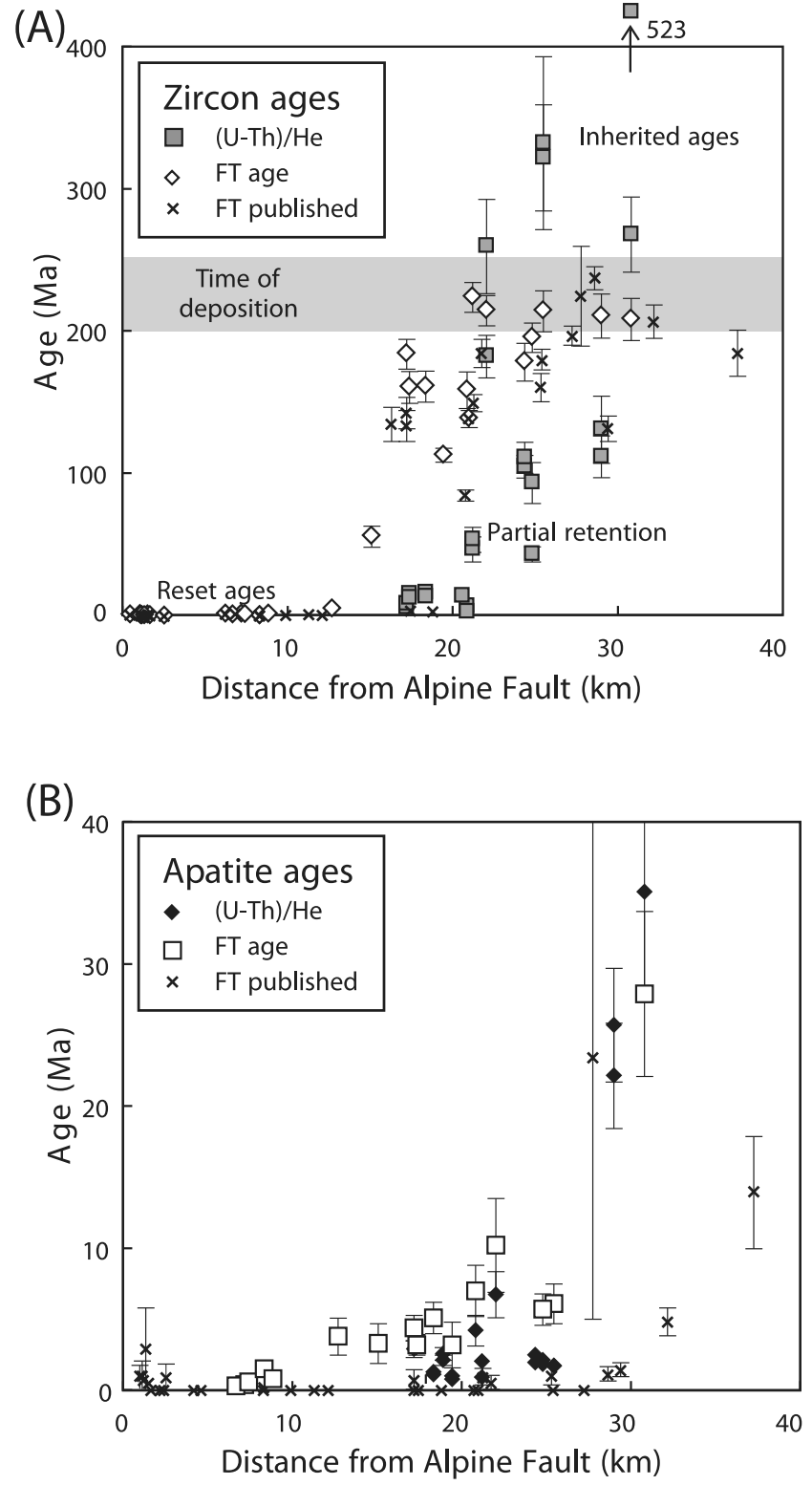

Figure 4. Thermochronologic data across the Southern Alps, plotted on a transect perpendicular to the Alpine Fault. (a) Zircon ages. (b) Apatite ages. Note the two different vertical scales. (U-Th)/He ages show combined analytical and size uncertainties, and FT ages show $1 \sigma$ uncertainties, using a bar symbol where these uncertainties are significantly larger than the size of the symbol. Published data also shown on the plots are from Tippett and Kamp [1993], Batt et al. [2000], and Herman et al. [2007a, 2007b].

[24] Given the complexity of the thermal structure near the surface and the effects it might have on the interpretation of the thermochronological data, it is not surprising to observe complex AERs in our data across faults of the Southern Alps. We therefore apply a 3-D thermokinematic model in an attempt to quantitatively interpret these data and isolate the effects of (1) large-scale variation of hori- zontal and vertical heat advection, (2) potential motion on individual faults east of the Main Divide, (3) constrain the tectonic boundary conditions on the regional deformation and exhumation, and (4) the interactions between exhumation and evolution of topography.

\subsection{Model Setup}

[25] We solve the heat transfer equation in three dimensions:

$$
\rho c\left(\frac{\partial T}{\partial t}+\vec{v} \nabla T\right)=k \nabla^{2} T+H+H_{s}
$$

where $T(x, y, z, t)$ is the temperature $(\mathrm{K}), \rho$ is rock density $\left(\mathrm{kg} \mathrm{m}^{-3}\right), c$ is heat capacity $\left(\mathrm{J} \mathrm{kg}^{-1} \mathrm{~K}^{-1}\right), \vec{v}(u, v, w)$ describes the velocity field $\left(\mathrm{km} \mathrm{Ma}^{-1}\right), k$ is the thermal conductivity $\left(\mathrm{W} \mathrm{m}^{-1} \mathrm{~K}^{-1}\right), H(x, y, z)$ is radioactive heat production per unit mass $\left(\mu \mathrm{W} \mathrm{m}^{-3}\right)$ and $H_{s}$ is shear heating $\left(\mu \mathrm{W} \mathrm{m}^{-3}\right)$.

[26] We use a modified version of a finite element code (Pecube [Braun, 2003; Herman et al., 2007a]) to solve equation (1) within a crustal block including the effects of a time-varying topography. We assume a crustal block that is $30 \mathrm{~km}$ thick and 60 by $60 \mathrm{~km}$ at the surface, using a resolution of $1 \mathrm{~km}$. The temperature at the base of the model is assigned to be $500^{\circ} \mathrm{C}$. The thermal diffusivity, $k$, is set to $30 \mathrm{~km}^{2} \mathrm{Ma}^{-1}$. The density $\rho$ is equal to $2700 \mathrm{~kg} \mathrm{~m}^{-3}$ and the heat capacity $c$ is equal to $1100 \mathrm{~J} \mathrm{~kg}^{-1} \mathrm{~K}^{-1}$. The radiogenic heat production is assigned to be $2 \mu \mathrm{W} \mathrm{m} m^{-3}$ [Pandey, 1972]. Shear heating is minimized since it has been suggested not to play a major role in the Southern Alps of New Zealand [Shi et al., 1996]. Finally, the model is run for $6 \mathrm{Ma}$.

[27] The chosen kinematics of the model follow the geodynamic model initially proposed by Wellman [1979] and subsequent models [e.g., Norris et al., 1990; Koons, 1990, 1994; Beaumont et al., 1996; Batt and Braun, 1999; Beavan et al., 2007; Herman et al., 2007a; Little et al., 2007]. We simulate uplift and exhumation on the Alpine Fault as well as near-vertical shearing and eastward rotation of the Pacific plate middle-upper crust (i.e., clockwise facing north) on the proside of the range using fault-bendfold rules [Suppe, 1983]. The rocks on the proside are assumed to ramp up in an escalator-like back shearing process (Figure 2b), similar to that of Little [2004], utilizing steeply dipping reverse faults (Figure 2c). Figure 6 portrays the kinematics we use in the model. Note that we only include the component of the plate motion perpendicular to the Alpine Fault, since the along strike component cannot be constrained by the thermochronological data. The Alpine Fault and detachment are modeled as a ramp made of three segments with decreasing dip from northwest to southeast (Figure 6). Note that the geometry was initially selected on the basis of general features observed in geophysical experiments [Davey et al., 2007], then tuned through an iterative process. Near the surface trace of the Alpine Fault, the dip of the main Alpine Fault ramp is defined by an angle $\alpha$, the middle segment is a lower ramp which dips eastward at an angle $\gamma$ and connects to the third segment, which is 

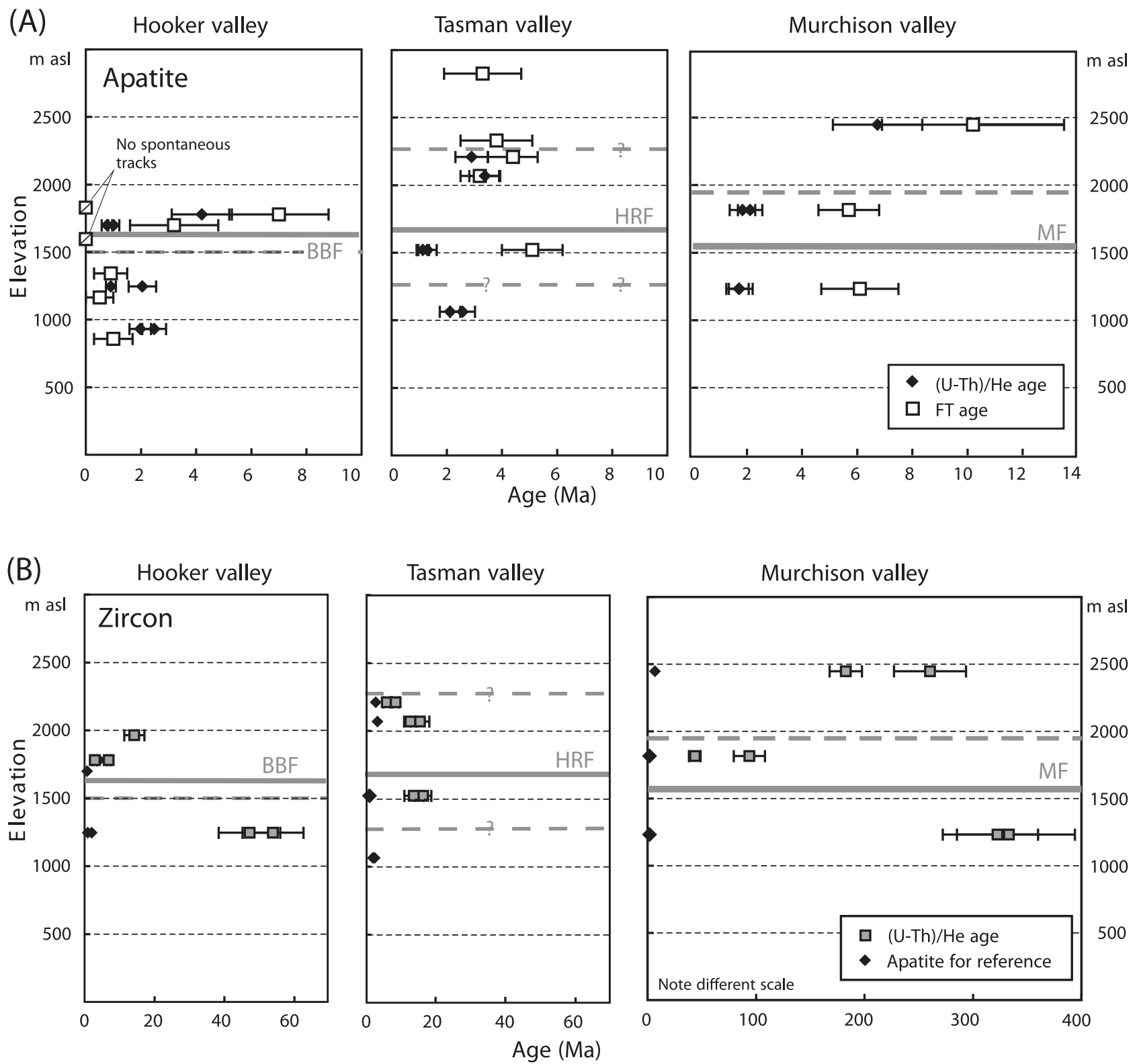

Figure 5. Age-elevation profiles for thermochronologic ages on the western sides of Hooker, Tasman and Murchison valleys, across the Black Blob (BBF), Haast Ridge (HRF) and Murchison faults (MF), respectively. (a) Apatite FT and (U-Th)/He ages. (b) Zircon (U-Th)/He ages, with apatite also plotted for reference.

equivalent to a flat detachment lying at a $25 \mathrm{~km}$ depth. $D$ $(\mathrm{km})$ defines the depth where the first and second segment connect. The dip of the back thrusts $\left(\beta=\frac{\pi-\alpha-\gamma}{2}\right.$ and $\omega=\frac{\pi-\gamma}{2}$ in Figure 6) results from the geometry of the ramp but is consistent with the orientation of fault exposures observed at the surface (i.e., $\beta=60^{\circ} \pm 10^{\circ}$ ). The width of the zone of high rock uplift associated with the Alpine Fault, $W(\mathrm{~km})$, results from the choice of $\alpha, D$ and $\gamma$. We show in Figure 7a how $W$ varies as a function of $\alpha$ and $D$ for a fixed $\gamma\left(=10^{\circ}\right)$. This parameter is of prime interest since it defines the locus of active fault-related vertical deformation within the orogen. The width to the edge of low rock uplift, $Y(\mathrm{~km})$, can be calculated in a similar manner, which is shown in Figure $7 \mathrm{~b}$. It is important to emphasize that, although there is a velocity gradient, any back thrusts forming or rupturing in this zone probably do not accumulate substantial finite long-term deformation as the rocks and fault are both advected toward the Alpine Fault.

[28] The evolution of the topography is treated in a simple manner. We advect the real topography toward the Alpine Fault, supposing that the topography migrates at the same rate as the tectonic velocity. We also assume that the relief has increased by $20 \%$ since the onset of enhanced glaciation (about $1.9 \mathrm{Ma}$ ), as it has been suggested recently 


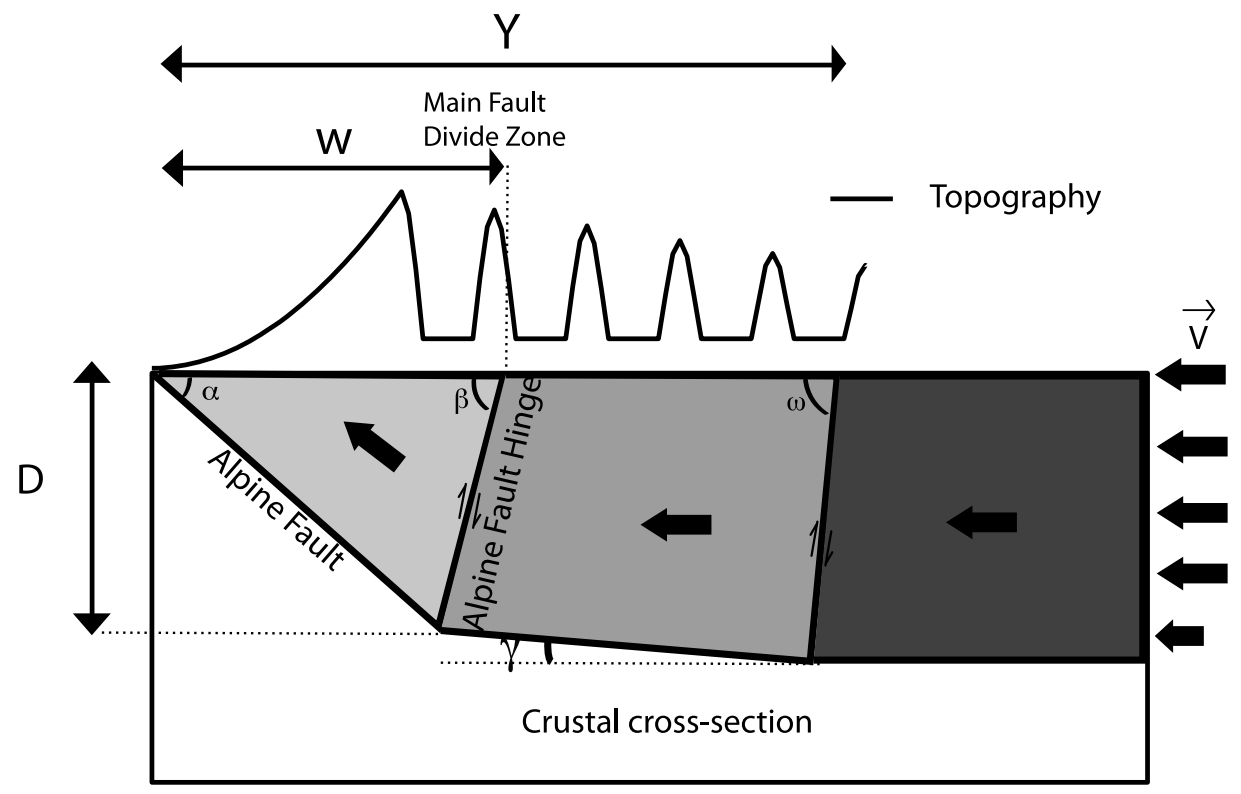

Figure 6. Sketch of the kinematic model used in Pecube. $D$ is the depth of connection between the first two segments, $\gamma$ describes the dip of the detachment in the central part of the range, $\vec{v}$ is the convergence velocity, $W$ is the width of the region of high exhumation/rock uplift, $Y$ is the width to the edge of low rock uplift, $\alpha$ is the dip of the Alpine Fault at the surface trace, $\beta$ is the dip of the back thrusts in the central zone, and $\omega$ is the dip of the back thrusts farther southeast.

for the Southern Alps [Herman et al., 2007a; Herman and Braun, 2008].

[29] At the end of the model run, we extract thermal histories to compute thermochronological ages for rocks that end up at the surface. (U-Th)/He ages are computed by solving the solid state diffusion equation, as described by Herman et al. [2007a, 2007b], whereas fission track annealing is simulated following the approach of van der Beek
[1995]. For the present study, we include the effects of radiation damage for the computation of apatite $(\mathrm{U}-\mathrm{Th}) / \mathrm{He}$ ages [Shuster et al., 2006; Flowers et al., 2007]. Instead of computing a single age for each sample, we compute a range of ages that better reflect the actual age distribution as a function of the amount of radiation damage experienced by each grain. It is worth emphasizing that the observed spread in age must also involve other mechanisms and the
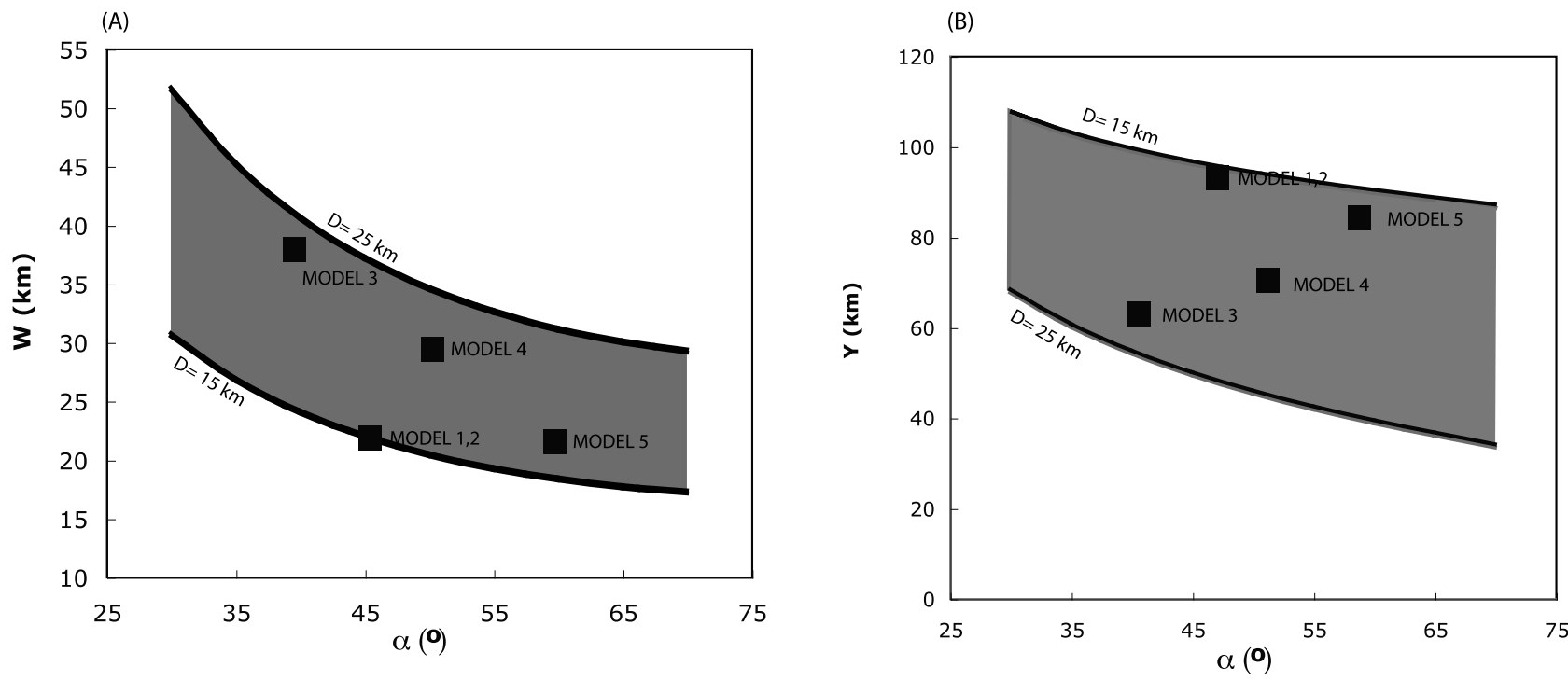

Figure 7. (a) $W$ and (b) $Y$ as a function of $\alpha$ for $\gamma$ set equal to $10^{\circ}$. 


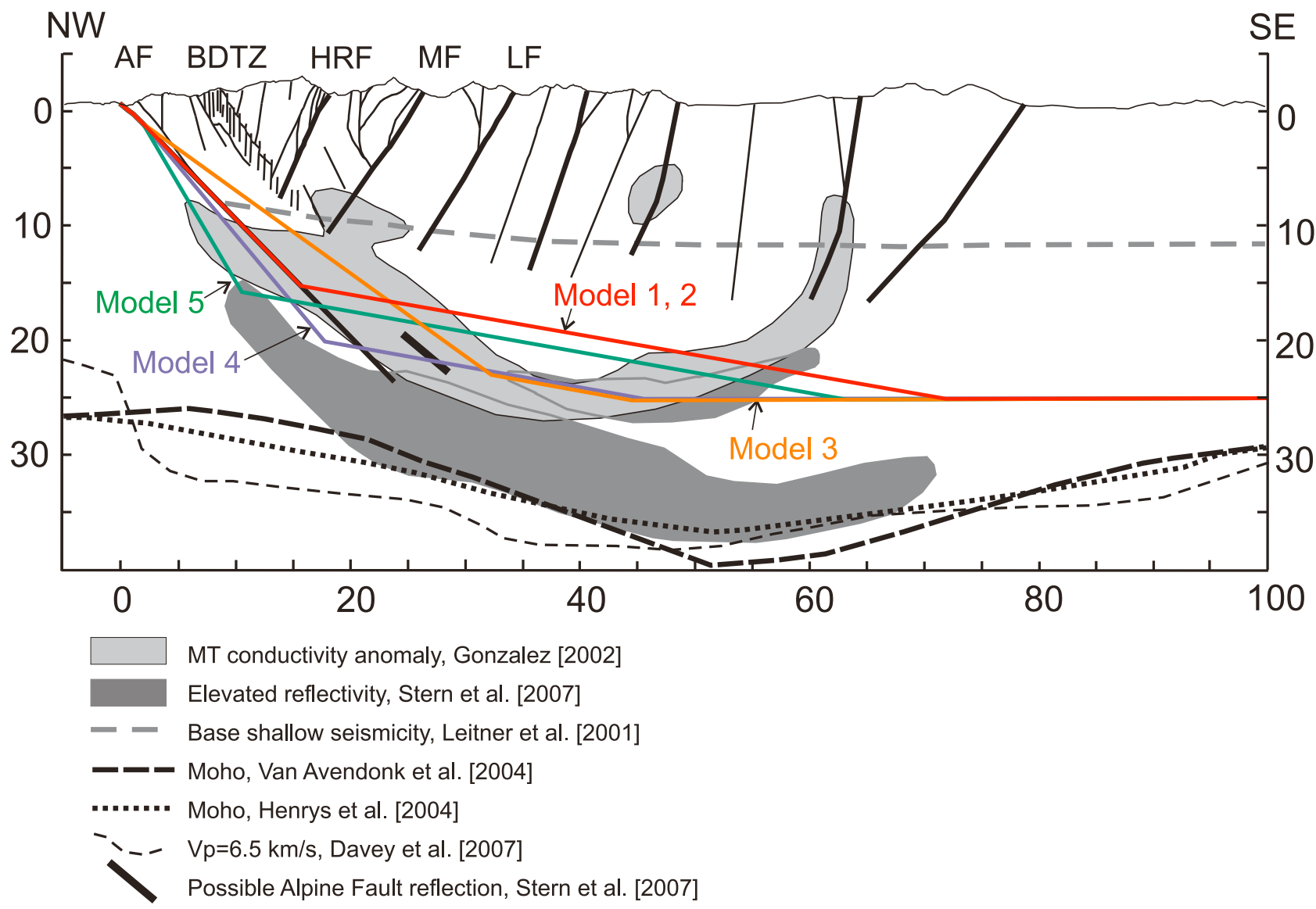

Figure 8. NW-SE cross section, drawn exactly to scale with no vertical exaggeration, showing the Alpine Fault, reverse back thrusts, and topography across the orogen with main geophysical interpretation overlain (as indicated). Note that the MT conductivity anomaly has been projected along strike nearly $40 \mathrm{~km}$ southwest and the elevated seismic reflectivity has been projected $10 \mathrm{~km}$ northeast to the location of this cross section. Geometry of the Alpine Fault and detachment ramp used in PECUBE is shown for models 1 to 5 .

approach adopted here should be seen as a means to predict a range of possible ages. We adopt the model described by Shuster et al. [2006]; in which the diffusivity is adjusted as a function of radiation damage

$$
D=D_{0} \frac{e^{\left(-E_{a} / R T\right)}}{\psi\left[{ }^{4} \mathrm{He}\right] e^{\left(E_{t} / R T\right)}+1}
$$

where $D$ is the diffusivity $\left(\mathrm{m}^{2} \mathrm{~s}^{-1}\right), D_{0}$ is the diffusivity at infinite temperature, $E_{a}$ is the activation energy $\left(\mathrm{J} \mathrm{mol}^{-1}\right)$, $E_{t}$ is the energy barrier, $R$ is the gas constant $\left(\mathrm{J} \mathrm{mol}^{-1} \mathrm{~K}^{-1}\right)$, $T$ is the temperature $(\mathrm{K}),\left[{ }^{4} \mathrm{He}\right]$ is the concentration of ${ }^{4} \mathrm{He}\left(\mathrm{mol} \mathrm{g}^{-1}\right)$, and $\psi$ is a constant. Using this approach, the closure temperature varies between 50 and $115^{\circ} \mathrm{C}$. The effects of radiation damage only becomes important in the partial retention zone. Finally, since the analyzed grains are detrital, an inherited age of $100 \mathrm{Ma}$ is assigned before reheating. This age corresponds to the average age of exhumation of these grains.

\subsection{Modeling Results}

[30] In this section, we start by describing the model predictions at the scale of the orogen and then focus on the local AERs across the different faults. The modeling results are summarized in Figure 9-12. The temperature field depends on a large number of parameters. Multiple tradeoffs occur, between thermal and geometric parameters. Rather than fully exploring the parameter space, we manually optimized the parameters by trial and error until a reasonable fit to the data was achieved. We only discuss here the implications of varying $\vec{v}$ and the key parameters that define the geometry (i.e., $\alpha, D$ and consequently $W$ and $Y$ ). The resulting geometry of the Alpine Fault ramp for each model is plotted to scale on the regional cross section in Figure 8.

[31] The thermal structure predicted by our first model, named model 1 , is closely linked with the imposed kinematics. In this model, $\vec{v}$ is equal to $9 \mathrm{~km} \mathrm{Ma}^{-1}$ and the choice of $\alpha$ and $D$ leads to $W$ equal to $22 \mathrm{~km}$ and $Y$ to $96 \mathrm{~km}$ (Table 3). The amount of shortening caused by the clock- 
Table 3. Geometric Parameters Varied for Models 1 to $5^{\text {a }}$

\begin{tabular}{cccccc}
\hline Model & $V\left(\mathrm{~mm} \mathrm{a}^{-1}\right)$ & $\alpha$ & $D(\mathrm{~km})$ & $W(\mathrm{~km})$ & $Y(\mathrm{~km})$ \\
\hline 1 & 9 & 45 & 15 & 22 & 96 \\
2 & 14 & 45 & 15 & 22 & 96 \\
3 & 9 & 37 & 23 & 38 & 67 \\
4 & 9 & 50 & 20 & 30 & 75 \\
5 & 9 & 60 & 16 & 22 & 91
\end{tabular}

${ }^{\mathrm{a}} V$ is the convergence velocity, $\alpha$ is the surface dip of the Alpine Fault, $D$ is the depth connecting the upper and lower ramp of the Alpine Fault, $W$ is the width of the zone of high rock uplift, and $Y$ the extent of the zone of uplift. These parameters are sketched in Figure 6.

wise rotation of material along the hinge of the Alpine Fault represents about $30 \%$ of the total shortening. The modeled geothermal gradient is higher adjacent to the Alpine Fault than in regions further east; which corresponds to that suggested by numerous studies [e.g., Allis, 1981; Koons, 1987; Shi et al., 1996; Batt et al., 2000; Herman et al., 2007a]. The thermochronological data clearly reflects this pattern. In Figure 9, we show 2-D projections of the predicted ages versus actual data. It illustrates how the regional pattern is reproduced: (1) Neogene ages near the Alpine Fault, (2) partially reset ages in the central block and (3) unreset Mesozoic ages occur toward the southeast. The width of the reset ages zone is inversely proportional to the closure temperature [e.g., Tippett and Kamp, 1993; Batt et al., 2000; Herman et al., 2007a; Reiners and Brandon, 2006]. Similarly, the width of the partially reset zone is also a function of the closure temperature (zircon FT and (U-Th)/ He ages increase from Neogene to Paleogene ages within a very narrow zone compared with apatite ages (Figures 9c and $9 \mathrm{~d})$ ).

[32] In model 2, we increase $\vec{v}$ to $14 \mathrm{~km} \mathrm{Ma}^{-1}$ (Table 3), which exceeds the expected convergent component of relative plate motion by at least $40 \%$ [Beavan et al., 2007]. The results for apatite (U-Th)/He ages with high radiation damage are compared to that of model 1 (Figure 10a). As expected, increasing the convergence velocity leads to a wider zone of young ages. These results indicate that, with the assumed geometry, one can fit the data only with a total convergence comparable to that derived from geodetic observations and plate tectonic reconstructions.

[33] We now vary the geometry of the problem through $\alpha$ and $D$ (in comparison with model 1). The resulting values of $W$ and $Y$ for each model are shown in Figure 7 and Table 3. In model 3, we assign a wider zone of high rock uplift by tuning $\alpha$ and $D$ equal to $37^{\circ}$ and $23 \mathrm{~km}$, respectively (Table 3), in turn setting up $W$ equal to $38 \mathrm{~km}$ and $Y$ to $67 \mathrm{~km}$. The results are plotted in Figure 10b. It again leads to a much wider zone of young ages. This model does not reproduce the partially reset ages observed in the central zone. In model 4 , we increase both $\alpha\left(=50^{\circ}\right)$ and $D(=20 \mathrm{~km})$ to set $W$ equal to $30 \mathrm{~km}$ and $Y$ to $75 \mathrm{~km}$, which also leads a wide zone of high rock uplift (Figure 10b). The fact that the zone of partially reset ages is narrower simply reflects that the lower ramp is very small, suggesting it is necessary to include a central zone with a moderate rock uplift rate to explain the partially reset ages. Finally, in model 5, we increase $\alpha$ to $60^{\circ}$ and slightly increase $D$ to keep $W$ and $Y$ comparable to model 1 (i.e., $\sim 22 \mathrm{~km}$ ). The modeled ages are very similar to those predicted by model 1, suggesting that the thermochronological data provide us with tight constraints on $W$.

[34] We continue our analysis of the modeling results by investigating the distribution of ages in plan view and the AERs across the different profiles. In Figure 11, we plot a perspective view of the ages predicted by model 1 overlain on the topography. It clearly illustrates how both the horizontal advection and topography affect the age distributions for each system. Apatite (U-Th)/He ages for both low and high radiation damage are shown in Figures 11a and $11 \mathrm{~b}$, respectively. The range of possible ages within the central partially reset zone appears to be very large. The model shows that near surface isotherms are perturbed at a regional scale by uplift and erosion, resulting in nonhorizontal equal age surfaces, as suggested above. This is also observed for the apatite FT ages (Figure 11c) and to a lesser extent for zircon (U-Th)/He and FT ages (Figures 11d and 11e). This in part explains why the Black Blob and Haast Ridge faults, which are on the hanging wall of the zone of greatest exhumation near the Alpine Fault, appear to have more complex AERs and smaller differences between apatite (U-Th)/He and FT ages compared with the Murchison Fault, which lies farther away to the southeast of the zone of main rock uplift. This is clearly illustrated when the predicted and observed AERs are compared (Figure 12). In Figure 12a, we plot both measured and modeled apatite (U-Th)/He (low radiation damage predicted ages are depicted by the blue dots and high radiation damage by the red dots) and FT (green dots). Predicted ages are extracted from grid points around the measured ages, as highlighted in Figure 12b. As discussed above, the positive slope of AER across the Murchison Fault is clearly reproduced for both systems. Topography appears to play a critical role to explain the partially reset ages at the top of the ridge, since rock uplift is moderate in this part of the range and in turn the isotherms corresponding to the closure of the system are less influenced by the shape of the topography. For the Tasman Valley profile, the negative slope of AER observed in the data is also modeled. In this case, however, horizontal distance between samples dominates the pattern, rather than topography or fault displacement. Finally, the first-order trend of the AER in the Hooker Valley can be explained. Note that no clear interpretation can be drawn since apatite FT ages are younger than apatite $(\mathrm{U}-\mathrm{Th}) / \mathrm{He}$ ages at the bottom of the ridge, which makes modeling of the data impossible.

\section{Discussion}

[35] During the early planning and design of this research it was hoped that low-temperature thermochronology data collected in transects across the faults might be able to provide detailed information on the timing of movement and amount of throw. However, we encountered poor data reproducibility, greater lateral than vertical variability on sloping ridgeline transects, and suspect the occurrence of 
(A) Apatite (U-Th)/He

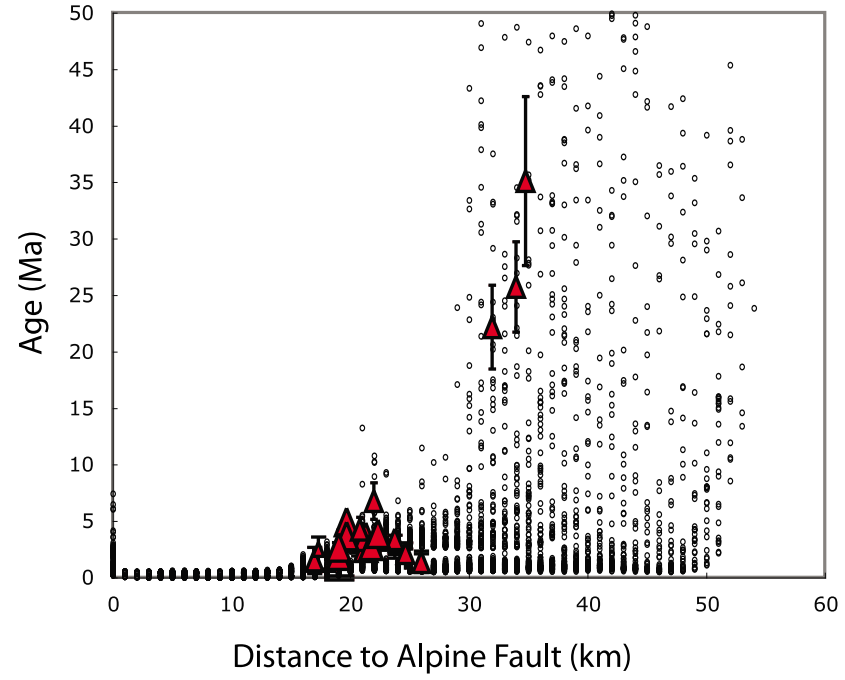

(C) Zircon (U-Th)/He

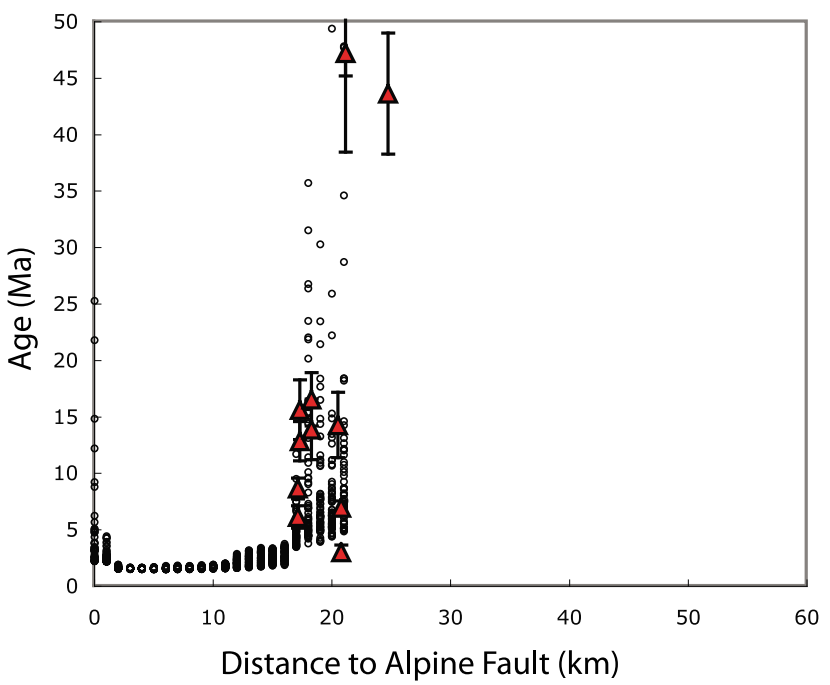

(B) Apatite Fission Track
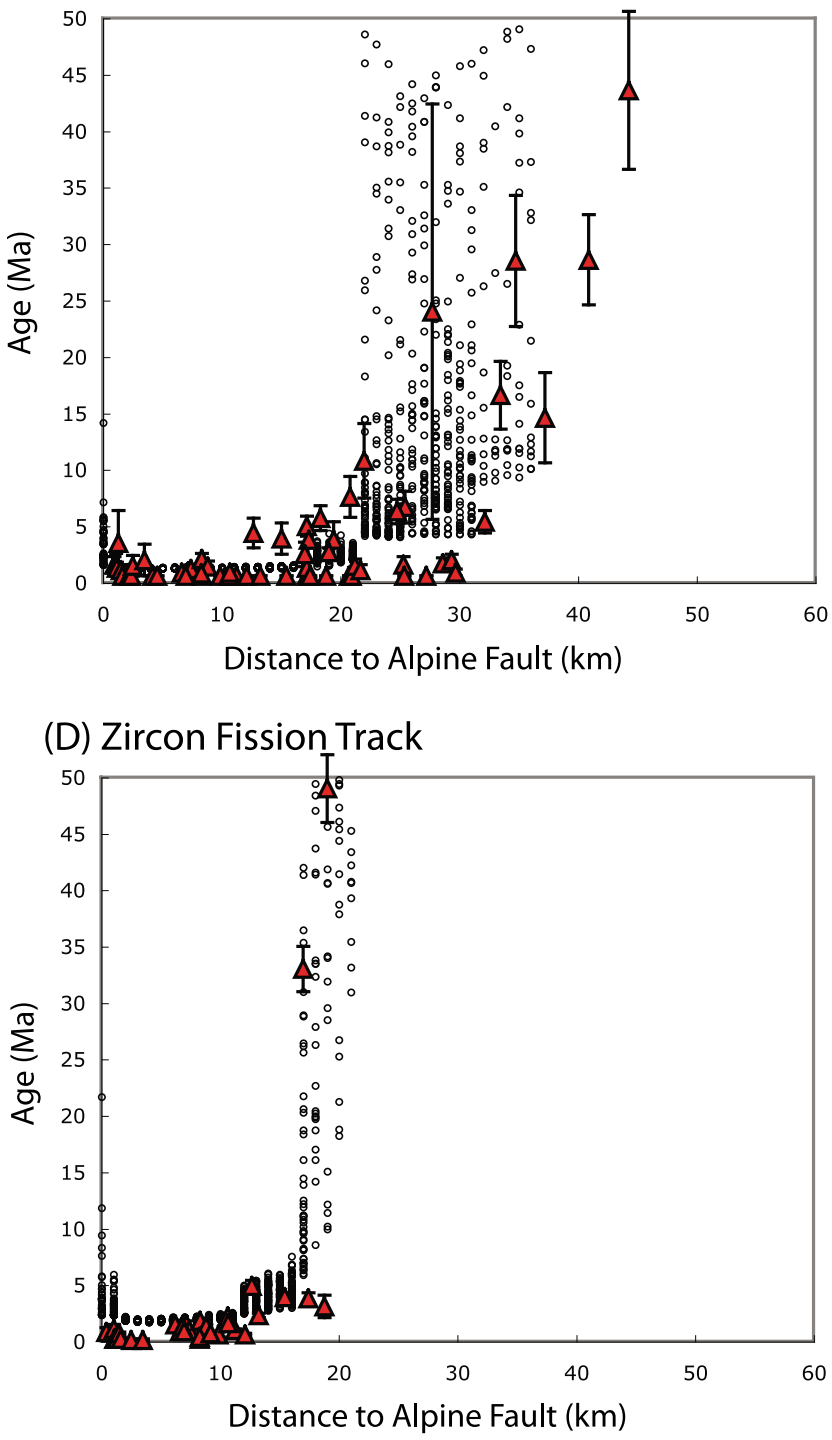

\section{- Modeled ages \\ $\Delta$ Measured ages}

Figure 9. Comparison between predicted and measured ages for model 1. Small circles depict predicted ages. Triangles with error bars depict actual data. (a) Apatite (U-Th)/He ages (both high and low radiation damage). (b) Apatite FT ages. (c) Zircon (U-Th)/He ages. (d) Zircon FT ages.

locally complex thermal structures, all of which hampered analysis of motion on individual faults. Being restricted to fine-grained detrital apatite and zircon in metamorphosed graywacke rocks of the Southern Alps, instead of young, coarse igneous grains, probably hampered our results. Instead, we obtained data which are much more useful for application at a regional scale. One particularly interesting observation revealed from the models is the complexity of the predicted AERs for the apatite (U-Th)/He ages induced by simply including the effects of radiation damage on the kinetic parameters used to compute the ages. Radiation damage may have been important for these rocks, since peak metamorphism occurred during the Mesozoic and many have remained at low temperatures, above or within the partial retention zone, for a long period prior to being uplifted during late Cenozoic collision. Beside the important effects of regional tectonic boundary conditions and evolution of topography, the modeling results therefore clearly illustrate the effects radiation damage might have on $(\mathrm{U}-\mathrm{Th}) / \mathrm{He}$ age evolution (compare in Figures 11a and 11b). In reality, the spread in ages might also stem from other complications such as grain size, inclusions, Sm content, 
(A)

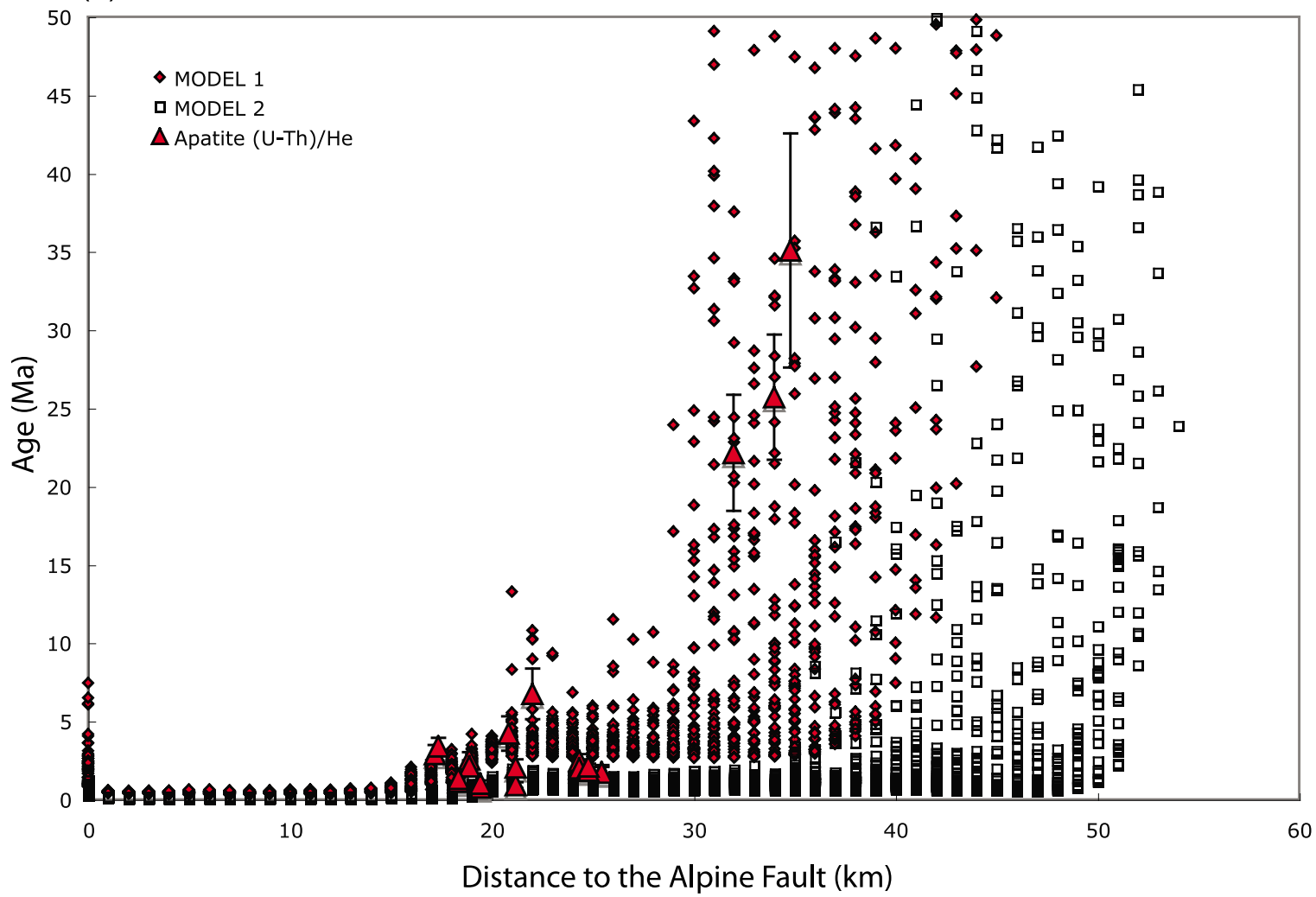

(B)

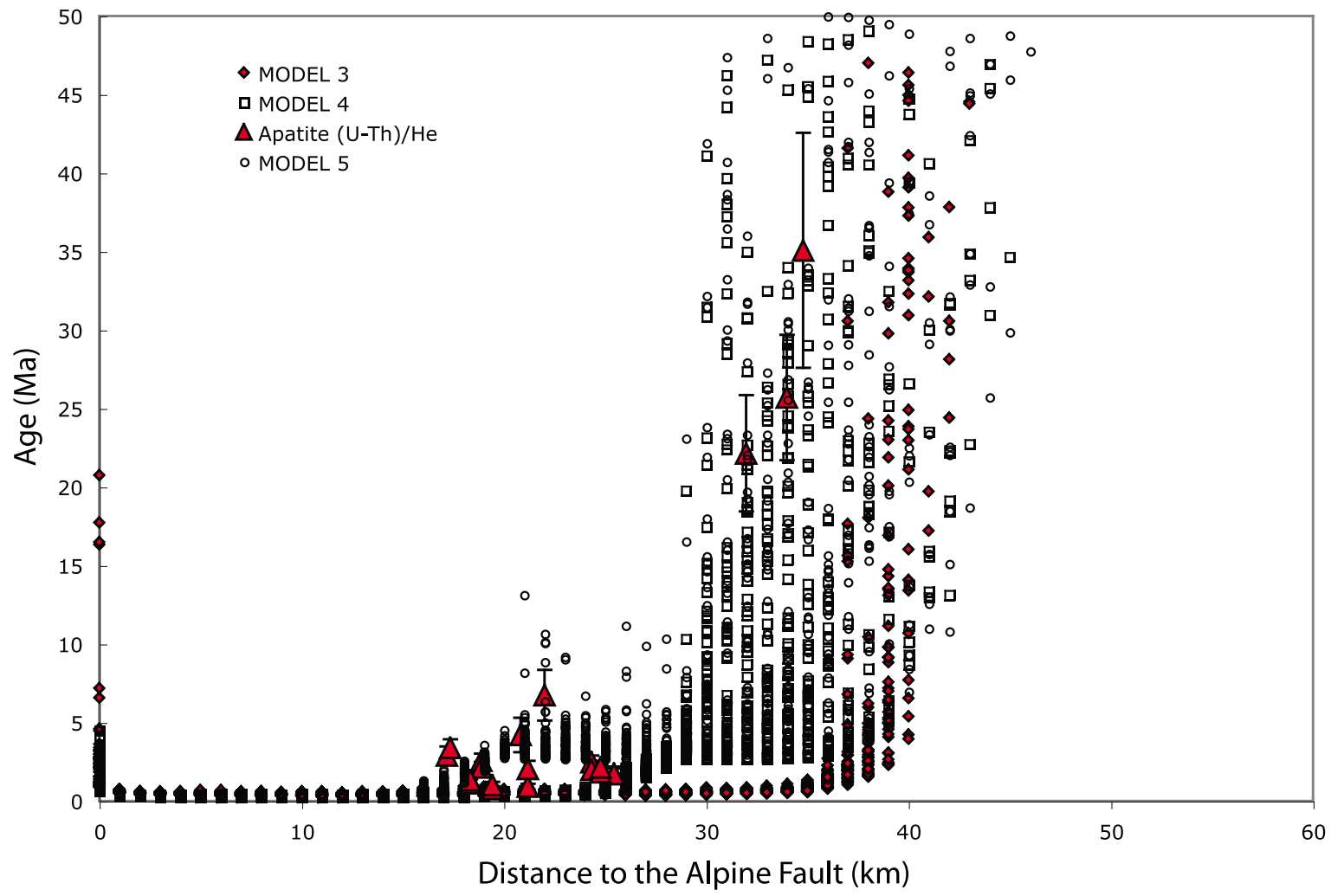

Figure 10. Apatite (U-Th)/He with high radiation damage predicted by the numerical model compared to actual data (large triangles with error bars). (a) Models 1 (filled diamonds) and 2 (open squares).

(b) Models 3 (filled diamonds), 4 (open squares) to 5 (open circles). 
(A) Apatite (U-Th)/He, low radiation damage

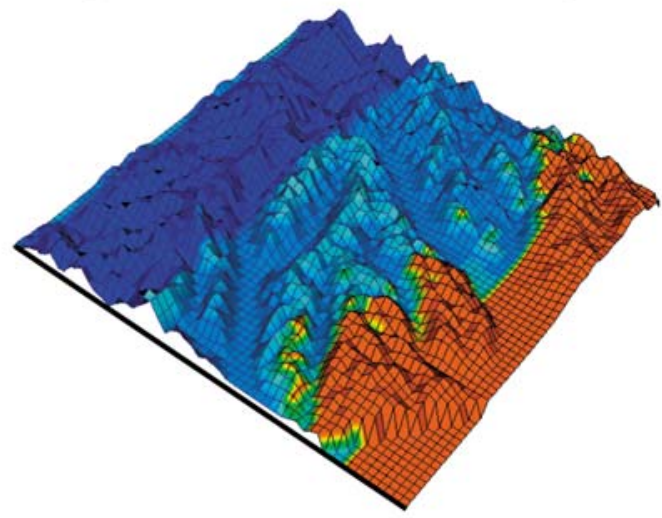

(C) Apatite Fission Track

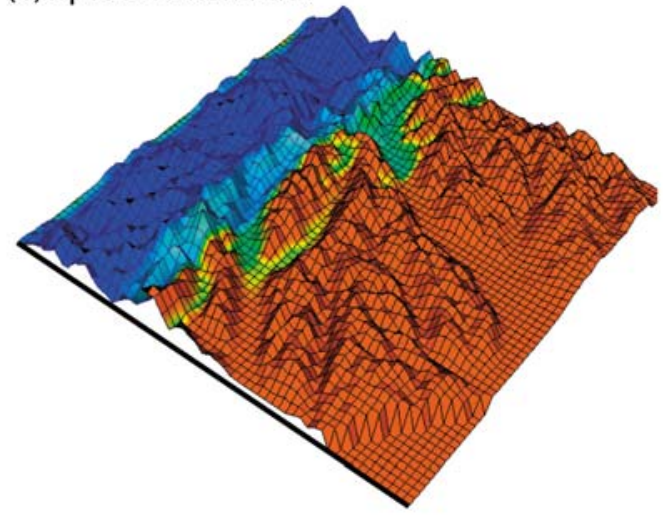

(B) Apatite (U-Th)/He, high radiation damage

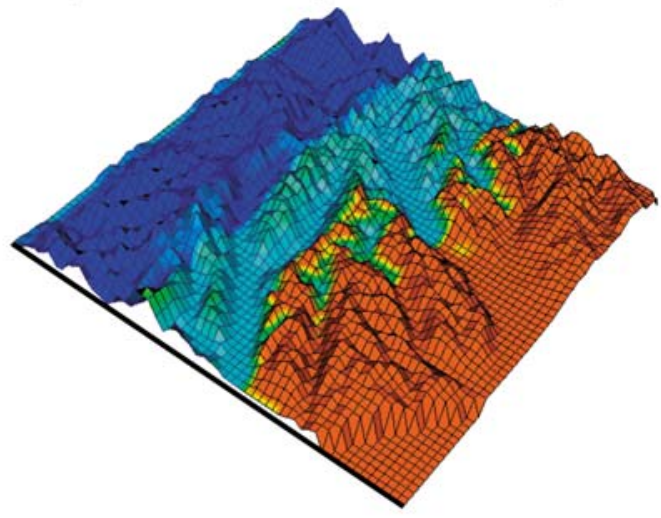

(C) Zircon (U-Th)/He

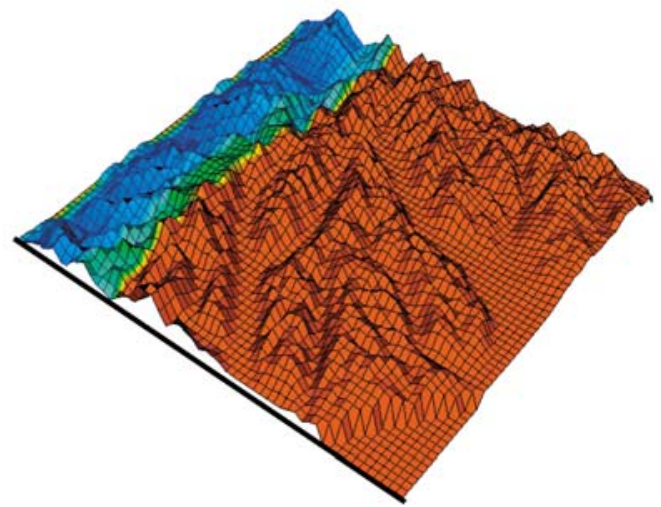

(F) Topography
(E) Zircon Fission Track

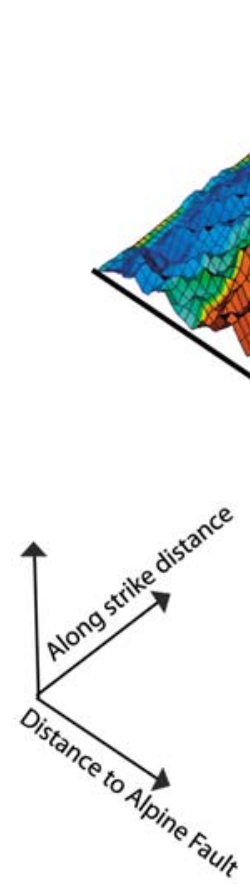

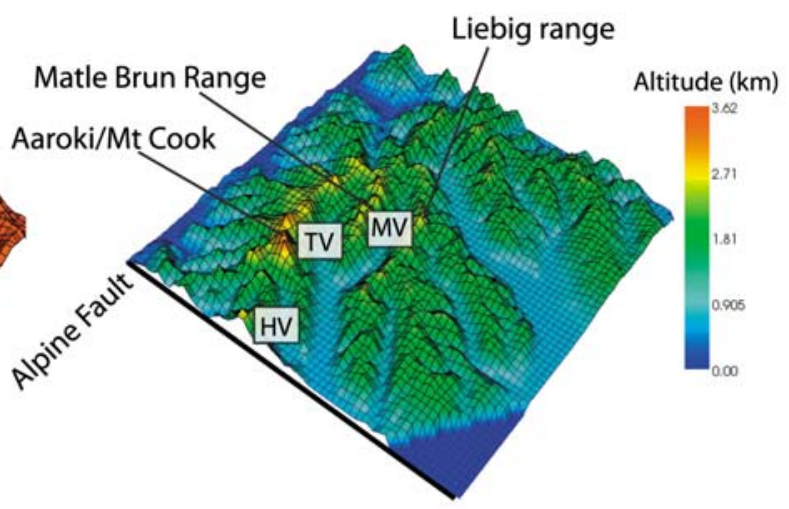

Figure 11. Perspective views of predicted ages for model 1. (a) Apatite (U-Th)/He ages with low radiation damage. (b) (U-Th)/He with high radiation damage. (c) Apatite FT ages. (d) Zircon (U-Th)/He ages. (e) Zircon FT ages. (f) Topography (HV, Hooker Valley; TV, Tasman Valley; MV, Murchison Valley). 

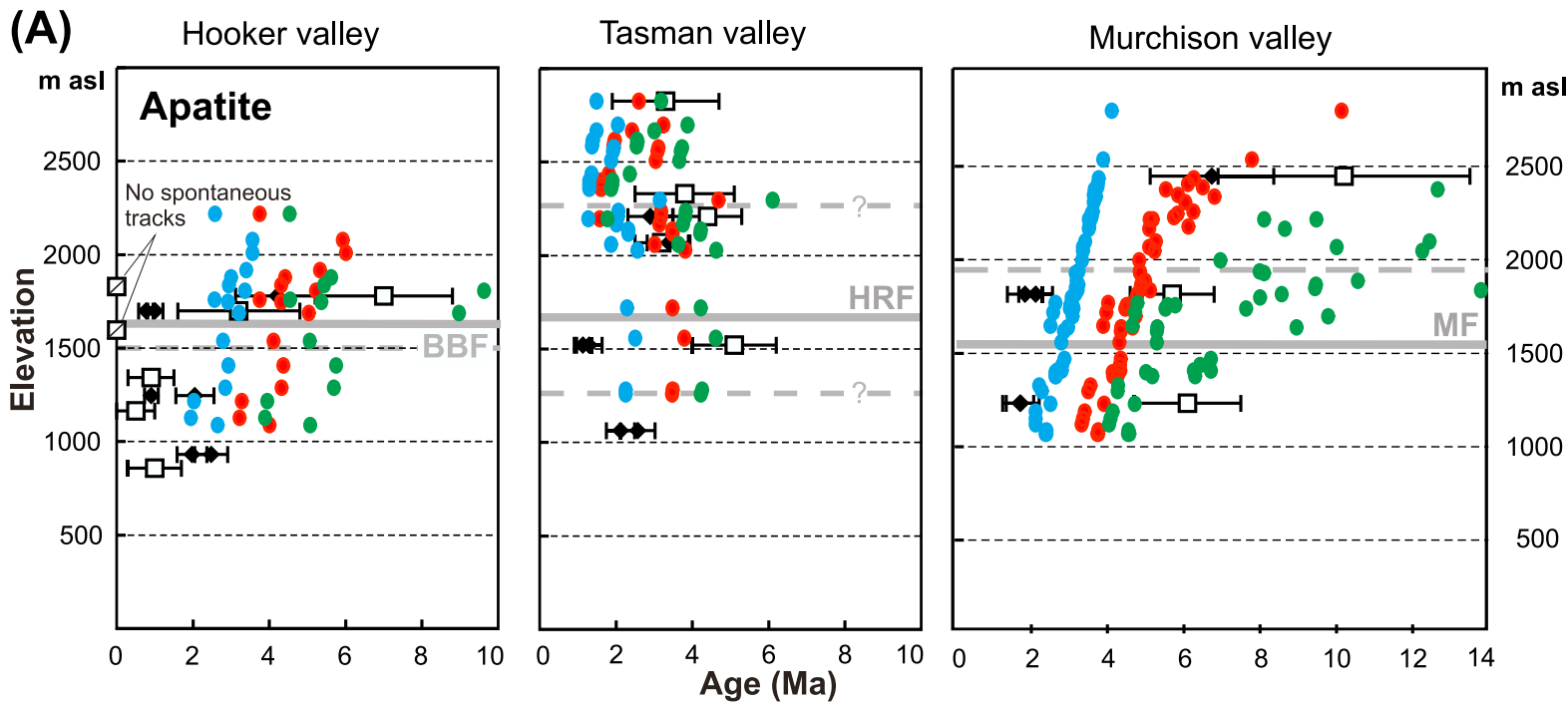

Observed ages:
$-\quad(\mathrm{U}-\mathrm{Th}) / \mathrm{He}$ age
$\square \quad$ FT age

Predicted ages:

- Apatite (U-Th)/He age, low radiation damage

- Apatite (U-Th)/He age, low radiation damage

- Apatite FT age

(B)

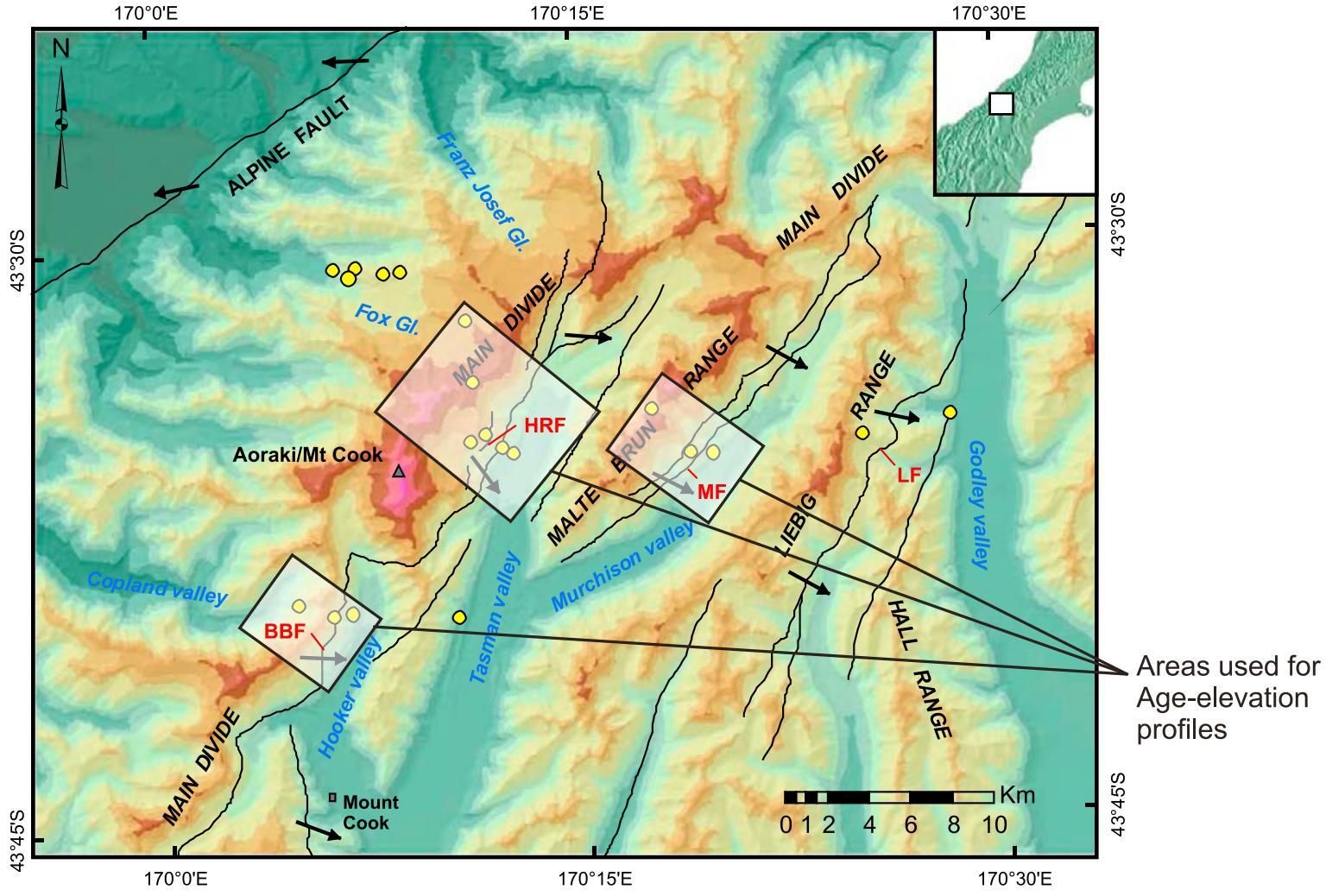

Figure 12. Comparison between predicted and observed AERs for model 1. (a) Predicted and observed AER for apatite (U-Th)/He and apatite FT across the three main profiles that have reset ages. Blue dots depict apatite (U-Th)/He with low radiation damage, red dots apatite (U-Th)/He with high radiation damage and green dots apatite FT ages as predicted by the model. (b) DEM showing the areas used for the predicted age-elevation profile in Figure 12a. 
zonation [e.g., Farley et al., 1996; Hourigan et al., 2005; Fitzgerald et al., 2006; Flowers et al., 2007; Herman et al., 2007b] that certainly influence the age distribution. It is however difficult to isolate the different mechanisms and the actual significance of radiation damage since we performed bulk analyses.

[36] The nature of rock deformation during movement over thrust fault ramps has been modeled in many analytical, numerical and analogue studies, as well as described from the field [e.g., Suppe, 1983; Kilsdonk and Wiltscho, 1988; Erickson and Jamison, 1995; Beaumont et al., 1996; Erickson et al., 2001]. Common to all models is the concentration of deformation above ramp hinges, with finite strains constrained and imposed by kinematic boundary conditions. Some modeling suggests discrete antithetic structures will preferentially develop where fault bends are sharp, with propagation of crosscutting back thrusts from the concentration of differential stress at the bend [e.g., Erickson and Jamison, 1995; Erickson et al., 2001]. Where fault bends are more rounded, or models have strong vertical contrasts in rheology, interlayer slip sometimes occurs. Thermokinematic modeling presented in this study generated rock uplift using two inclined ramps within the Pacific plate as it is translated through the orogen. Ramp geometry was varied to examine the effects of the kinematic boundary conditions on the modeled ages. The different geometries of the models are illustrated in a cross section drawn exactly to scale (Figure 8), and compared to the location and geometry of geophysical features observed during recent Southern Alps experiments. Our favored models, which best fit the observed Southern Alps thermochronologic ages, have a $45-60^{\circ}$ dipping Alpine Fault intersecting a $10^{\circ} \mathrm{SE}$ dipping ramp at a relatively shallow depths (model 1 and 5), with convergence velocity of $9 \mathrm{~mm}$ $\mathrm{a}^{-1}$ equivalent to GPS and plate tectonic models. This Alpine Fault dip value corresponds to the most commonly accepted value for the central portion of the fault based on structural arguments, modeling of geodetic deformation, and imaging by geophysical experiments [see Davey et al., 2007; Stern et al., 2007, and references therein]. While the presence of a flat detachment at $25-30 \mathrm{~km}$ is also commonly proposed beneath the eastern side of South Island, a shallow $10^{\circ} \mathrm{SE}$ dipping ramp is newly suggested by our work. This wide ramp is situated on the western side of the crustal root, subparallel to the dip of the Moho in this region, connecting a flat lying, or possibly east dipping, detachment with the Alpine Fault (Figure 8). The modeled ramp corresponds approximately with the position and orientation of a conductive zone [Gonzalez, 2002], interpreted to be an interconnected network of fluid-filled porosity facilitated by shearing, fracturing, and/or grain edge wetting in actively deforming ductile crust beneath the Alps.

[37] The regional map pattern comprising deeply exhumed high-grade schists in the west and lower-grade rocks to the east suggests that some degree of Pacific plate rotation must occur in the collision zone, although the mechanism by which this occurs may vary in different parts of the crust, as suggested in the original concepts of
Wellman [1979] and illustrated in Figure 1b. Geophysical modeling of South Island flexural rigidity suggests there is effectively no elastic strength in the crust and mantle, so strain and deformation is inferred to be accommodated by either ductile flow or upper crustal faulting [Stern et al., 2007]. In the Alpine Schist, an up ramping of $31^{\circ}$ is recorded on near-vertical shears [Holcombe and Little, 2001] while semischist rocks have been subjected to oblique slip on brittle-ductile shears which accounts for $22 \pm 8^{\circ}$ of up ramping [Wightman and Little, 2007]. Lowgrade graywackes in the east have always remained at shallow crustal levels above the brittle-ductile transition, so the most likely structures for rotation are the numerous faults, found at a variety of scales, throughout the graywacke sequences. S. C. Cox and F. Herman (Kinematics of the principal faults within an oblique convergent plate boundary zone, central Southern Alps, New Zealand, manuscript in preparation, 2009) examined 1655 bedding orientations in graywackes across the eastern side of the Southern Alps, classified in structural domains between faults (domains A to F of Cox and Herman (manuscript in preparation, 2009)). From southeast to northwest, bedding goes from steeply dipping within domains $\mathrm{C}$ to $\mathrm{F}$ to less steeply dipping in domains $\mathrm{A}$ and $\mathrm{B}$. They interpreted eastward tilting of $23^{\circ}$ and $30^{\circ}\left( \pm 8^{\circ}\right)$ for sequences west of the Murchison and Black Blob-Haast Ridge faults, respectively. The structural observations of rotation recorded in schist, semischist, and graywacke parts of the crustal section suggest a bulk vertical shear strain of 0.6 , and are consistent with a $35^{\circ}$ degree difference between a low angle ramp ( $10^{\circ}$ dip) and the Alpine Fault $\left(45-60^{\circ}\right.$ dip), as proposed by our preferred models. If the transition involved translation direct from a flat-lying detachment directly onto a $45-60^{\circ}$ Alpine Fault, an additional distributed strain would need to be invoked, as suggested by Wightman and Little [2007].

[38] The thermokinematic models suggest there should be two distinct zones of uplift within the Alps, similar to the inboard wedge and outboard wedge proposed by Koons [1994]. Defining the total width of the orogen is very dependent on geometrical calculations of dip, but the preferred thermokinematic models suggest the outermost ramp related deformation should occur about 91-96 km from the Alpine Fault (model 1 and 5), which more or less corresponds to the position of faults at the edge of the Canterbury Plains and the easternmost exposure of basement rocks at the Canterbury range front. High uplift rates are modeled to reach $\sim 22 \mathrm{~km}$ from the Alpine Fault in the preferred thermokinematic scenarios, which corresponds to the location of the Murchison Fault. Observed rotation of bedding west of the Murchison Fault, but not to the east, corroborates well with modeling results. The high-uplift zone might possibly extend as far as the Liebig Fault, but only if the Alpine Fault has a shallow dip (model 3) or the intersection depth D is $20 \mathrm{~km}$ (model 4).

[39] The thermochronologic data and modeling suggest the principal faults of the central Southern Alps are situated where rupture is likely to be in response to a concentration of differential stress from a marked change in ramp orien- 
tation. We note, however, that the thermokinematic models only consider the shortening component of the plate deformation. While these faults are predominantly dip slip in nature they strike slightly oblique to the Alpine Fault and are oriented so that they also accommodate a component of along-strike motion. The thermochronological work is unable to clearly define the extent to which fault rupture is purely a ramp-related process or a response to differential stresses associated with along-strike deformation, nor the extent to which any motion might be coupled with the Alpine Fault rupture cycle. We encourage other disciplines to investigate this phenomenon further.

\section{Conclusions}

[40] Our modeling of existing and new thermochronological data enables us to address aspects of the tectonics of the Southern Alps of New Zealand.

[41] 1. The newly established apatite and zircon (U-Th)/ $\mathrm{He}$ and FT data set corroborates previous observations, with young Neogene ages in the vicinity of the Alpine Fault, partially reset ages in the central Southern Alps and older Mesozoic ages to the southeast, simply reflecting the firstorder kinematics of the orogen. Data are for the most part consistent with theoretical systematics for steadily exhumed rocks, with zircon apparent ages older than apatite apparent ages for the equivalent method.

[42] 2. Three-dimensional thermokinematic modeling of the low-temperature thermochronological ages requires a two-stage ramping of Pacific plate material in order to reproduce regional patterns in the observed ages. Pacific plate material is initially uplifted on a gentle southeast dipping ramp above the western side of the crustal root, then increases as the crust ramps up the Alpine Fault. The preferred, best fit, thermokinematic model has a steeply dipping Alpine Fault $\left(45-60^{\circ}\right)$, joining at a $15 \mathrm{~km}$ deep lower ramp dipping at $10^{\circ}$, and resulting in a $\sim 22 \mathrm{~km}$ wide high uplift zone. Modeling suggests the driving force for rupture on the principal faults of the central Southern Alps is likely to be the concentration of differential stress associated with the geometrical change during translation across the lower ramp and onto the Alpine Fault.

[43] 3. The effects of radiation damage on apatite (U-Th)/ He is shown to have dramatic effects and in part enables to explain the complexity of age-elevation relationships in observed Southern Alps data.

[44] Acknowledgments. The authors would like to thank the Department of Conservation (DOC) for their help and logistical support in the field. Simon Cox's involvement was funded under GNS Science's Impacts of Global Plate Tectonics in and around New Zealand Programme (PGST contract C05X0203) and QMAP, Geological Map of New Zealand (PGST contract C05X0401). Frédéric Herman was funded by the Australian Research Council (Jean Braun's ARC discovery grant DP0342909). Peter Kamp was funded under FRST contract UOWX0301 to University of Waikato. (U-Th)/He data were acquired at the Research School of Earth Sciences, Australian National University. We thank Courtney Gregory for picking apatite and zircon crystals, Xiaodong Zhang for his help in the noble gas laboratory, and Charlotte Allen for her help with the ICP-MS. Irradiation of apatite and zircon for FT analyses were performed in the X-7 facility of the HIFAR reactor, New South Wales, Australia. Fission track data were acquired in the Department of Earth and Ocean Sciences, University of Waikato. We thank Xu Ganqing for technical assistance. We also wish to thank our colleagues Rupert Sutherland, Tim Little, and Jean Braun for discussions and helpful comments, although not necessarily implying their total agreement with all the arguments presented. The authors would also like to thank James Spotila and two anonymous reviewers for their helpful comments and suggestions.

\section{References}

Adams, C. J. (1980), Contemporary uplift rates and erosion of the Southern Alps, New Zealand, Geol. Soc. Am. Bull., Part 2, 91, 1-114.

Adams, C. J., and J. E. Gabites (1985), Age of metamorphism and uplift in the Alpine Schist Group at Haast Pass, Lake Wanaka and Lake Hawea, South Island, New Zealand, N. Z. J. Geol. Geophys., 28, $85-96$.

Allis, R. G. (1981), Changes in heat flow associated with exploitation of Wairakei geothermal field, New Zealand, N. Z. J. Geol. Geophys., 24, 1-19.

Armstrong, P. A., T. A. Ehlers, D. S. Chapman, K. A Farley, and P. J. J. Kamp (2003), Exhumation of the central Wasatch Mountains, Utah: 1. Patterns and timing of exhumation deduced from low-temperature thermochronology data, J. Geophys. Res., 108(B3), 2172, doi:10.1029/2001JB001708.

Batt, G. E., and J. Braun (1997), On the thermomechanical evolution of compressional orogens, Geophys. J. Int., 128, 364-382, doi:10.1111/j.1365-246X. 1997.tb01561.x.

Batt, G. E., and J. Braun (1999), The tectonic evolution of the Southern Alps, New Zealand: Insights from fully thermally coupled dynamical modelling, Geophys. J. Int., 136, 403-420, doi:10.1046/ j.1365-246X.1999.00730.x.

Batt, G. E., J. Braun, B. P. Kohn, and I. McDougall (2000), Thermochronological analysis of the dynamics of the Southern Alps, New Zealand, Geol. Soc. Am. Bull., 112(2), 250-266, doi:10.1130/ 0016-7606(2000)112<0250:TAOTDO >2.3.CO;2.
Beaumont, C., P. J. J. Kamp, J. Hamilton, and P. Fullsack (1996), The continental collision zone, South Island, New Zealand: comparison of geodynamical models and observations, J. Geophys. Res., 101, 3333-3359, doi:10.1029/95JB02401.

Beavan, J., S. Ellis, L. Wallace, and P. Denys (2007), Kinematic Constraints from GPS on Oblique Convergence of the Pacific and Australian Plates, Central South Island, New Zealand, in A Continental Plate Boundary: Tectonics at South Island, New Zealand, Geophys. Monogr. Ser., vol. 175, edited by D. Okaya, T. Stern, and F. Davey, pp. 75-94, AGU, Washington, D. C.

Berger, A. L., J. A. Spotila, J. B. Chapman, T. L. Pavlis, E. Enkelmann, N. A. Ruppert, and J. T. Buscher (2008), Architecture, kinematics, and exhumation of a convergent orogenic wedge: A thermochronological investigation of tectonic-climatic interactions within the central St Elias orogen, Alaska, Earth Planet. Sci. Lett., 270(1-2), 13-24, doi:10.1016/j.eps1.2008. 02.034 .

Brandon, M., M. Roden-tice, and J. Graver (1998), Late Cenozoic exhumation of the Cascadia accretionary wedge in the Olympic mountains, Geol. Soc. Am. Bull., 110, 985-1009, doi:10.1130/ 0016-7606(1998) $110<0985$ :LCEOTC $>2.3$. CO;2.

Braun, J. (2002), Quantifying the effect of recent relief changes on age-elevation relationship, Earth Planet. Sci. Lett., 200, 331-343, doi:10.1016/ S0012-821X(02)00638-6.
Braun, J. (2003), Pecube: A new finite element code to solve the heat transport equation in three dimensions in the Earth's crust including the effects of a time-varying, finite amplitude surface topography, Comput. Geosci., 29(6), 787-794, doi:10.1016/ S0098-3004(03)00052-9.

Cande, S., and J. Stock (2004), Pacific-Antarctic- Australia motion and the formation of the Macquarie plate, Geophys. J. Int., 157, 399-414, doi:10.1111/ j.1365-246X.2004.02224.x.

Cox, S. C., and D. J. Barrell (2007), Geology of the Aoraki area, 1:250,000 geological map, 1 sheet + 71 pp., technical report, Inst. of Geol. and Nucl. Sci., Lower Hutt, New Zealand.

Cox, S. C., and R. H. Findlay (1995), The Main Divide Fault Zone and its role in the formation of the Southern Alps, N. Z. J. Geophys. Geol., 38, 489-500.

Cox, S. C., and R. Sutherland (2007), Regional geological framework of South Island, New Zealand, and its significance for understanding the active plate boundary, in A Continental Plate Boundary: Tectonics at South Island, New Zealand, Geophys. Monogr. Ser., vol. 175, edited by D. Okaya, T. Stern, and F. Davey, pp. 19-46, AGU, Washington, D. C.

Cox, S. C., D. Craw, and C. P. Chamberlain (1997), Structure and fluid migration in a late Cenozoic duplex system forming the Main Divide in the central Southern Alps, New Zealand, N. Z. J. Geol. Geophys., 40(3), 359-373. 
Davey, F. J., D. Eberhart-Phillips, M. Kohler, S. C. Bannister, G. Caldwell, S. Henrys, M. Scherwath, T. Stern, and H. van Avendonk (2007), Geophysical structure of the Southern alps Orogen, South Island, New Zealand, in A Continental Plate Boundary: Tectonics at South Island, New Zealand, Geophys. Monogr. Ser., vol. 175, edited by D. Okaya, T. Stern, and F. Davey, pp. 47-73, AGU, Washington, D. C

Dodson, M. H. (1973), Closure temperature in cooling geochronological and petrological systems, Contrib. Mineral. Petrol., 40, 259-274, doi:10.1007/ BF00373790.

Ehlers, T. A., and K. A. Farley (2003), Apatite (U-Th) He Thermochronometry: Methods and applications to problems in tectonics and surface processes, Earth Planet. Sci. Lett., 206, 1-14, doi:10.1016 S0012-821X(02)01069-5.

Erickson, S. G., and W. R. Jamison (1995), Viscousplastic finite-element models of fault-bend folds, $J$ Struct. Geol., 17, 561-573, doi:10.1016/0191 8141(94)00082-B.

Erickson, S. G., L. Strayer, and J. Suppe (2001), Initiation and reactivation of faults during movemen over a thrust-fault ramp: numerical mechanica models, J. Struct. Geol., 23, 11-23, doi:10.1016/ S0191-8141(00)00074-2.

Farley, K. A. (2000), Helium diffusion from apatite: General behavior as illustrated by Durango fluorapatite, J. Geophys. Res., 105, 2903-2914, doi:10.1029/1999JB900348.

Farley, K. A., R. Wolf, and L. Silver (1996), The effect of long alpha-stopping distances on (U-Th)/He dates, Geochim. Cosmochim. Acta, 60, 4223 4229, doi:10.1016/S0016-7037(96)00193-7.

Fitzgerald, P., S. Baldwin, L. Webb, and P. O'Sullivan (2006), (U-Th)/He data from slowly cooled crustal terranes and the interpretation of intra-sample variations of single crystal apatite ages from vertical profiles, Chem. Geol., 225, 91-120, doi:10.1016/ j.chemgeo.2005.09.001.

Flowers, R. M., D. L. Shuster, B. P. Wernicke, and K. A. Farley (2007), Radiation damage contro on apatite (U-Th)/He dates from the Grand Canyon region, Colorado Plateau, Geology, 35(5), $447-$ 450, doi:10.1130/G23471A.1.

Galbraith, R. F. (1981), On statistical models for fission track counts, J. Math. Geol., 13, 471-478, doi:10.1007/BF01034498.

Galbraith, R. F., and P. F. Green (1990), Estimating the component ages in a finite mixture, Nucl. Tracks Radiat. Meas., 17, 197-206.

Garver, J., and P. Kamp (2002), Integration of zircon color and zircon fission track zonation patterns in Orogenic belts: Application of the Southern Alps, New Zealand, Tectonophysics, 349(1-4), $203-$ 219, doi:10.1016/S0040-1951(02)00054-9.

Gonzalez, V. M. (2002), Magnetotelluric evidence for mid-crustal fluids in an active transpressive continental orogen, South Island, New Zealand, Master's thesis, San Diego State Univ., San Diego, Calif.

Grapes, R., and T. Watanabe (1983), Metamorphism and Uplift of the Alpine schists in the Franz-Josef-Fox Glacier area of the Southern Alps of New Zealand, Eur. J. Mineral., 4, 547-555.

Grasemann, B., and N. S. Mancktelow (1993), Twodimensional thermal modeling of normal faulting: the Simplon fault zone, central Alps, Switzerland, Tectonophysics, 225, 155-165, doi:10.1016/00401951(93)90277-Q.

Green, P. F., I. R. Duddy, A. J. W. Gleadow, P. R. Tingate, and G. M. Laslett (1986), Thermal annealing of fission tracks in apatite 1. A qualitative description, Chem. Geol., 59, 237-253, doi:10.1016/ 0009-2541(86)90048-3.

Green, P. F., I. R. Duddy, G. M. Laslett, K. A. Hegarty, A. J. W. Gleadow, and J. F. Lovering (1989), Thermal annealing of fission tracks in apatite 4. Quantitative modelling techniques and extension to geological timescales, Chem. Geol. $79,155-182$.
Griffiths, G. A., and M. J. McSaveney (1983), Distribution of mean annual precipitation across some steepland regions of New Zealand, N. Z. J. Sci. 26, 197-209.

Harrison, T. M., F. J. Ryerson, P. Le Fort, A. Yin, O. M. Lovera, and E. J. Catlos (1997), A late MiocenePliocene origin for the central himalayan inverted metamorphism, Earth Planet. Sci. Lett., 146, E1 E8, doi:10.1016/S0012-821X(96)00215-4

Henrys, S. A., D. J. Woodward, D. Okaya, and J. Yu (2004), Mapping the Moho beneath the Southern Alps continent-continent collision, New Zealand, using wide-angle reflections, Geophys. Res. Lett., 31, L17602, doi:10.1029/2004GL020561.

Herman, F., and J. Braun (2006), Fluvial response to horizontal shortening and glaciations: A study in the Southern Alps of New Zealand, J. Geophys. Res., 111, F01008, doi:10.1029/2004JF000248.

Herman, F., and J. Braun (2008), Evolution of the glacial landscape of the Southern Alps of New Zealand: Insights from a glacial erosion model. J. Geophys. Res., 113, F02009, doi:10.1029 2007JF000807.

Herman, F., J. Braun, and W. Dunlap (2007a), Tectonomorphic scenarios in the Southern Alps of New Zealand, J. Geophys. Res., 112, B04201, doi:10.1029/2004JB003472.

Herman, F., J. Braun, T. Senden, and W. Dunlap (2007b), (U-Th)/He chronometry: Mapping 3D geometry using micro-X-ray tomography and solving the associated production-diffusion equation Chem. Geol., 242(1-2), 126-136, doi:10.1016 j.chemgeo.2007.03.009.

Hicks, D. M., J. Hill, and U. Shankar (1996), Variation of suspended sediment yields around New Zealand: The relative importance of rainfall and geology, in Erosion and Sediment Yield: Global and Regional Perspectives, edited by D. E. Walling and B. W. Webb, IAHS Publ., 236, 149-156.

Holcombe, R. J., and T. A. Little (2001), A sensitive vorticity gauge using rotated porphyroblasts, and its application to rocks adjacent to the Alpine Fault New Zealand, J. Struct. Geol., 23, 979-990, doi:10.1016/S0191-8141(00)00169-3.

Hourigan, J. K., P. W. Reiners, and M. T. Brandon (2005), U-Th zonation-dependent alpha-ejection in (U-Th)/He chronometry, Geochim. Cosmochim. Acta, 69(13), 3349-3365, doi:10.1016 j.gca.2005.01.024

House, M. A., B. P. Wernicke, and K. A. Farley (1998), Dating topography of the Sierra Nevada, California, using apatite (U-Th)/He ages, Nature, 396, 66-69, doi:10.1038/23926.

Kamp, P. J. J. (1997), Paleogeothermal gradient and deformation style, Pacific front of the Southern Alps Orogen: Constrains from fission track thermochronology, Tectonophysics, 271, 37-58, doi:10.1016/S0040-1951(96)00246-6.

Kamp, P. J. J., P. F. Green, and S. H. White (1989), Fission track analysis reveals character of collisional tectonics in New Zealand, Tectonics, 8(2), 169-195, doi:10.1029/TC008i002p00169.

Kilsdonk, B., and D. V. Wiltscho (1988), Deformation mechanisms in the southeastern ramp region of Pine Mountain block, Tennessee, Geol. Soc. Am Bull., 100, 653-664, doi:10.1130/00167606(1988) $100<0653:$ DMITSR $>2.3 . C O ; 2$

Koons, P. O. (1987), Some thermal and mechanical conseqences of rapid uplift: an example from the Southern Alps, New Zealand, Earth Planet. Sci. Lett., 86, 307-319, doi:10.1016/0012 821X(87)90228-7.

Koons, P. O. (1990), Two-sided orogen: collision and erosion from the sandbox to the Southern Alps, New Zealand, Geology, 18, 679-682, doi:10.1130/0091-7613(1990)018<0679:TSO $\mathrm{CAE}>2.3 . \mathrm{CO} ; 2$

Koons, P. O. (1994), Three-dimensional critica wedges: Tectonics and topography in oblique collisional orogens, J. Geophys. Res., 99, 12,30112,315, doi:10.1029/94JB00611.
Koons, P. O., R. J. Norris, D. Craw, and A. F. Cooper (2003), Influence of exhumation on the structura evolution of transpressional plate boundaries; An example from the Southern Alps, New Zealand, Geology, 31, 3-6, doi: $10.1130 / 0091$ 7613(2003)031<0003:IOEOTS $>2.0 . \mathrm{CO} ; 2$

Leitner, B., D. Eberhart-Phillips, H. Anderson, and J. Nabelek (2001), A focused look at the Alpine Fault, New Zealand: Seismicity, focal mechanisms, and stress observations, J. Geophys. Res., 106, 2193-2220, doi:10.1029/2000JB900303.

Little, T. A. (2004), Transpressive ductile flow and oblique ramping of lower crust in a two-sided orogen: insight from quartz grain-shape fabrics near the Alpine Fault, New Zealand, Tectonics, 23, TC2013, doi:10.1029/2002TC001456

Little, T. A., R. J. Holcombe, and B. R. Ilg (2002a) Ductile fabrics in the zone of active oblique convergence near the Alpine Fault, New Zealand: Identifying the neotectonic overprint, J. Struct. Geol., 24(1), 193-217, doi:10.1016/S0191 8141(01)00059-1.

Little, T. A., R. J. Holcombe, and B. R. Ilg (2002b), Kinematics of oblique collision and ramping in ferred from microstructures and strain in middle crustal rocks, central Southern Alps, New Zealand, J. Struct. Geol., 24(1), 219-239, doi:10.1016/ S0191-8141(01)00060-8.

Little, T. A., S. Cox, J. Vry, and G. Batt (2005), Variations in exhumation level and uplift-rate along the oblique-slip Alpine fault, central Southern Alps, New Zealand, Geol. Soc. Am. Bull., 117, $707-$ 723, doi:10.1130/B25500.1.

Little, T. A., H. R. J. R. Wightman, and M. Hill (2007), Transpression models and ductile deformation of the lower crust of the Pacific Plate in the central Southern Alps, a perspective from structural geology, in A Continental Plate Bound ary: Tectonics at South Island, New Zealand, Geophys. Monogr. Ser., vol. 175, edited by D. Okaya, T. Stern, and F. Davey, pp. 271-288, AGU, Washington, D. C

Long, D. T., S. C. Cox, S. C. Bannister, M. C Gerstenberger, and D. Okaya (2003), Upper crustal structure beneath the eastern Southern Alps and the Mackenzie Basin, New Zealand, derived from seismic reflection data, N. Z. J. Geol. Geophys., 46(1), $21-39$.

Norris, R. J., and A. F. Cooper (2001), Late Quaternary slip rates and slip partitioning on the Alpine Fault, New Zealand, J. Struct. Geol., 23(2-3), 507-520, doi:10.1016/S0191-8141(00)00122-X.

Norris, R. J., and A. F. Cooper (2003), Very high strains recorded in mylonites along the Alpine Fault, New Zealand: implications for the deep structure of plate boundary faults, J. Struct. Geol. 25(12), 2141-2157, doi:10.1016/S0191-8141(03) $00045-2$

Norris, R. J., and A. F. Cooper (2007), The Alpine Fault New Zealand, in A Continental Plate Boundary Tectonics at South Island, New Zealand, Geophys. Monogr. Ser., vol. 175, edited by D. Okaya, T. Stern, and F. Davey, pp. 157-175, AGU, Washington, D. C. Norris, R. J., P. O. Koons, and A. F. Cooper (1990), The obliquely convergent plates in the South Island of New Zealand: Implications for ancient collision zones, J. Struct. Geol., 12(5-6), 715-725 doi:10.1016/0191-8141(90)90084-C.

Okaya, D., T. Stern, F. Davey, S. Henrys, and S. C. Cox (2007), Continent-continent collision at the Pacific/Indo-Australian plate boundary: background, motivation, and principal results, in A Continental Plate Boundary: Tectonics at South Island, New Zealand, Geophys. Monogr. Ser., vol. 175 edited by D. Okaya, T. Stern, and F. Davey, pp. 1-18, AGU, Washington, D. C.

Pandey, M. R. (1972), Terrestrial heat flow in New Zealand, Ph.D. thesis, Victoria Univ. of Wellington, Wellington, New Zealand.

Reiners, P., and M. Brandon (2006), Using thermochronology to understand orogenic erosion, Annu. 
Rev. Earth Planet. Sci., 34, 419-466, doi:10.1146/ annurev.earth.34.031405.125202.

Reiners, P. W., T. L. Spell, S. Nicolescu, and K. A Zanetti (2004), Zircon (U-Th)/He thermochronometry: He diffusion and comparisons with ${ }^{40} \mathrm{Ar} /{ }^{39} \mathrm{Ar}$ dating, Geochim. Cosmochim. Acta, 68 1857-1887, doi:10.1016/j.gca.2003.10.021.

Shi, Y., R. Allis, and F. Davey (1996), Thermal modelling of the Southern Alps, New Zealand, Pure Appl. Geophys., 146, 469-501, doi:10.1007/ BF00874730.

Shuster, D. L., R. M. Flowers, and K. A. Farley (2006), The influence of natural radiation damage on helium diffusion kinetics in apatite, Earth Planet Sci. Lett., 249(3-4), 148-161, doi:10.1016/ j.epsl.2006.07.028

Stern, T., D. Okaya, S. Kleffman, M. Scherwath, S. Henrys, and F. Davey (2007), Geophysical exploration and dynamics of the Alpine fault zone, in A Continental Plate Boundary: Tectonics at South Island, New Zealand, Geophys. Monogr. Ser., edited by D. Okaya, T. Stern, and F. Davey, pp. 207-233, AGU, Washington, D. C.

Stockli, D. F., K. A. Farley, and T. A. Dumitru (2000), Calibration of the apatite (U-Th)/He thermochronometer on an exhumed fault block, White Mountains, Calif. Geol., 28, 961-1056.
Stüwe, K., L. White, and R. Brown (1994), The influence of eroding topography on steady-state isotherms: Application to fission track analysis, Earth Planet. Sci. Lett., 124, 63-74, doi:10.1016/ 0012-821X(94)00068-9.

Suppe, J. (1983), Geometry and kinematics of fault bend folding, Am. J. Sci., 283, 684-721.

Sutherland, R. (1995), The Australia-Pacific boundary and Cenozoic plate motions in the SW Pacific Some constraints from Geosat data, Tectonics, 14(4), 819-831, doi:10.1029/95TC00930.

Tippett, J. M., and P. J. J. Kamp (1993), Fission track analysis of the late Cenozoic vertical kinematics of continental Pacific Crust, South Island, New Zealand, J. Geophys. Res., 98, 16,119-16,148, doi: $10.1029 / 92$ JB02115.

Van Avendonk, H. J. A., W. S. Holbrook, D. Okaya J. K. Austin, F. Davey, and T. Stern (2004), Continental crust under compression: A seismic refraction study of South Island Geophysical Transect I, South Island, New Zealand, J. Geophys. Res., 109, B06302, doi:10.1029/2003JB002790.

van der Beek, P. (1995), Tectonic evolution of continental rifts, Ph.D. thesis, Fac. of Earth Sci., Free Univ., Amsterdam, Netherlands.

Walcott, R. I. (1998), Present tectonics and late Cenozoic evolution of New Zealand, Rev. Geophys. 36, 1-26, doi:10.1029/97RG03084.
Wellman, H. (1979), An uplift map for the South Island of New Zealand, and a model for uplift of the Southern Alps, in The Origin of the Southern Alps, edited by R. I. Walcott and M. M. Cresswell, Bull. R. Soc. N. Z, 18, 13-20.

Wightman, R., and T. A. Little (2007), Deformation of the pacific plate above the alpine fault ramp and its relationship to expulsion of metamorphic fluids: An array of backshears, in $A$ Continental Plate Boundary: Tectonics at South Island, New Zealand, Geophys. Monogr. Ser., vol. 175, edited by D Okaya, T. Stern, and F. Davey, pp. 177-205, AGU, Washington, D. C.

Willett, S., C. Beaumont, and P. Fullsack (1993), Mechanical model for the tectonics of doubly-vergen compressional orogens, Geology, 21, 371-374, doi:10.1130/0091-7613(1993)021<0371: MMFTTO $>2.3 . \mathrm{CO} ; 2$.

S. C. Cox, GNS Science, 764 Cumberland Street, Private Bag 1930, Dunedin, 9054, New Zealand. (s.cox@gns.cri.nz)

F. Herman, Earth Sciences Department, ETH Zurich, Haldenbachstrasse 44, CH-8092 Zurich, Switzerland. (frederic@erdw.ethz.ch)

P. J. J. Kamp, Department of Earth and Ocean Sciences, University of Waikato, Gate 1 Knighton Road, Private Bag 3105, Hamilton 3240, New Zealand. 